\title{
Assessing the conundrums of the Cuban economy under the revolution (1959-2019)
}

\author{
C. Mesa-Lago \\ University of Pittsburgh, \\ 4200, Fifth Ave, Pittsburg, PA, 15260, USA
}

For citation: Mesa-Lago C. (2020) Assessing the conundrums of the Cuban economy under the revolution (1959-2019). St Petersburg University Journal of Economic Studies, vol.36, iss.3, pp.455-482. https://doi.org/10.21638/spbu05.2020.305

\begin{abstract}
This article evaluates the resilient challenges faced by Cuba's economy during the six decades of the Revolution (1959-2019), mainly its historical external economic dependency upon a foreign country (the USSR and Venezuela) and the adverse consequences that occur when such relationship ends or deteriorates. Several hypotheses address that issue as well as others such as the hindrance of the US embargo/blockade aggravated by Donald Trump's punitive sanctions and Cuban continuity of a centrally planned economy and predominance of state enterprises over the market and the non-state sector. The core is an analysis of performance of key economic indicators: GDP growth, gross capital formation, financial stability, mining-industry-agriculture output, tourism and exports of professional services. Hypotheses are tested with long-term statistical series elaborated and scrutinized by the author over half a century based on Cuban official sources, as well as legislation, articles by Cuban scholars and from news media. Among the results: external dependency has declined somewhat but demands deeper economic reforms, there are no countries currently capable and willing to fully replace Venezuela's substantial aid, the ongoing crisis provoked by the deteriorating Venezuelan economy cum Trump's sanctions should have lesser adverse effects than the 1990s crisis that resulted from the USSR disappearance. The article is a significant contribution to the study of Cuba's external economic dependence and its consequences, and should be also worthy for other small economies and socialist countries.

Keywords: Cuban economy 1959-2019, external economic dependence, USSR and Venezuela economic relationships, evaluation of economic performance, impact of Venezuelan crisis and Trump sanction on Cuba, crises, anti-crisis policies.
\end{abstract}

\section{Introduction and review of the literature}

This article is a pioneer in the evaluation of the Cuban economy in the 60 years since the Revolution, given the dearth of scholarly work on the entire period, except for the occasional assessment of previous periods [Mesa-Lago, 1971; 1981; Zimbalist, Eckstein, 1987; Rodríguez, 1989]. Historically, Cuba has endured economic dependence on a foreign country: before the Revolution with Spain and the Unites States, and under the Revolution with the USSR and Venezuela. Economic dependence in general was the subject of deep analysis and heated debate in the 1960s and the 1970s around "dependency theory", mostly elaborated by Latin American economists; this theory claimed that in the world capitalist system, developed countries exploit developing countries to extract a surplus that allows the former to thrive at the cost of the latter [Chase-Dunn, 2015]. Fidel Castro

() Санкт-Петербургский государственный университет, 2020 
argued, however, that such an exploitative relationship did not happen within the socialist camp: "The existence of an everyday increasing world socialist market permits economic cooperation and trade relations between developed and underdeveloped countries under conditions of independence (which) are very different than those existing between capitalists countries and their politico-economic colonies as was the case of the United States and Cuba. In this case, economic relations only function in behalf of the interest of the powerful nation contributing to keep their partners in a situation of underdevelopment" [Informe de la Delegación de Cuba, 1969, pp. 49-50]. There is no doubt that the relationship with the USSR was quite beneficial for Cuba. The question is that despite it, Cuba failed to become more independent, and hence the collapse of the USSR had disastrous economic consequences for the island.

De Miranda argues that Cuba's world insertion, typical of an underdeveloped country, determined the subordinated situation of the country in international economic relations; he studied how Cuban economic dependence (with Spain, the United States, the USSR, and Venezuela) persisted regardless of changes in Cuba's economic-political system [De Miranda, 2009]. Santamaria develops a profound historical analysis of Cuba's relations and economic dependency with Spain during the colonial period and beyond [Santamaria, 2004].

There is a fair consensus that Cuba was economically dependent on the Unites States, e. g., $68.6 \%$ of the island trade was with the USA, and she was recipient of the second largest U.S. investment in Latin America [Mesa-Lago, 1971]. Conversely, there was sharp disagreement on the results of such relationship: Marxists economists contended that the outcome was negative for Cuba and impeded a satisfactory degree of independence [Boorstein,1968; O'Connor, 1970], whereas market economists held the opposite view, claiming that Cuba was in the way of development precisely due to her ties with the United States [CERP, 1965; Farber, 2011]. One major goal of the Revolution was to eliminate such dependence.

In a history of the Cuban economy under the Revolution, the author used seven variables to assess performance, one of which was external dependence on the USSR based on two indicators: trade concentration/diversification ${ }^{1}$ and trade partner concentration. Other indicators were fuel supply, price subsidies to Cuban exports and Soviet imports, and other economic aid [Mesa-Lago, 2000]. Pérez-López analyzed Cuban economic relations with the CMEA, as well as trade subsidies and aid from the bloc to Cuba and how they disappeared with the dissolution of the CMEA and the USSR collapse [Pérez-López, 1991].

On Cuban dependence on Venezuela, Romero pinpoints two major features of the relationship: Venezuela's support through an "international subsidy" and the international projection of the alliance via an "ideological package" for other countries; he explores three alternative scenarios and decides for a continued relation despite serious difficulties [Romero, 2018]. Vidal measures the value of the economic relationship and assesses the impact of the "Venezuelan shock" on the Cuban economy [Vidal, 2014]. Hernández-Catá compares the worth of Cuba's economic relationship with the USSR and Venezuela, the subsequent chocks

\footnotetext{
${ }^{1}$ An anonymous referee questioned whether a high concentration of exports could be an indicator of dependence; the answer is positive but not necessarily on external dependence on another country. In the case of Cuba, however, high export concentration on sugar was related to high trade partner concentration with both the USA and the USSR.
} 
provoked by the collapse/deterioration of the helper country, and their different magnitude [Hernández-Catá, 2013]. Mesa-Lago and Vidal provide a comprehensive analysis of the relationship: its historical evolution, its overall value and major elements (the exchange of fuel for professional services, trade of goods and investment), its decline, and a projection of the cost for Cuba of losing Venezuela's vital pipeline [Mesa-Lago, Vidal, 2019].

This article goes beyond all previous work, setting hypotheses on three constant factors in the 60 years of the Cuban revolution (dependence on USSR and Venezuela, a model of central planning and the US embargo/blockade) and how they have shaped economic performance; testing them with statistics and other materials.

\section{Methodology}

The article has four interconnected hypotheses.

Hypothesis 1a. Despite the medium-term benefits of Cuba's dependence on the USSR and Venezuela, in the long-run the island has been unable to transform its economic structure in order to attain self-sustainable economic growth and steady development, specifically to finance her imports with her own exports, without price subsidies (to exports and/or imports) provided by the foreign partner;

Hypothesis 1b. When the economic relationship with the foreign partner ends (USSR) or significantly deteriorates (Venezuela), the Cuban economy suffers a severe crisis, difficult to overcome.

Hypothesis $2 a$. Compounding the dependency problem, two additional adverse factors are: internally, Cuba's economic model of central planning and the overwhelming role of state enterprises and collectivized agriculture over the market and private property; and, externally, the American embargo/blockade imposed since 1962 and tightened under Donald Trump's administration.

Hypothesis 2b. The combination of external dependence, an inefficient economic model, and the embargo/blockade has led to a poor economic performance.

Hypothesis 3. The degree of Cuba's economic dependence has declined somewhat under the Revolution: the ongoing crisis caused by the Venezuelan crisis cum Trump's sanctions probably will be of lesser magnitude than the 1990s crisis caused by the disappearance of Soviet aid.

Hypothesis 4. There is a low probability that another powerful foreign country (Russia or China) fully replaces Venezuela.

Testing the four hypotheses relies on primary empirical data: long-term statistical series elaborated and scrutinized over half a century by the author based on Cuba's main official source: the National Office of Statistics and Information (Oficina Nacional de Estadísticas e Información - ONEI). Due to changes in methodology to calculate Cuba's gross domestic product (GDP) and other key macro indicators, it is impossible to have an entire series for the revolutionary period 1959-2018, therefore most comparisons are based on the year 1989 - before the collapse of the USSR and when the Cuban economy was at its peak - and 2018 (the latest year available for statistics). In other cases, the focus is placed on the period of Raúl Castro's economic reforms (2007-2017). Additional primary data comes from the U.N. Economic Commission for Latin America and the Caribbean (ECLAC), valuable to do comparisons of Cuba's economic performance with that of other countries in the region. Third primary source is Cuban legislation particularly from 
the last decade. Secondary sources are scholarly publications of Cuban economists, as well as Cuban leaders' speeches, and newspapers and blogs both from inside and outside Cuba. The author's numerous works published in the last 55 years on the Cuban economy provide additional support on this endeavor. Data for the article ends on November 15, 2019.

\section{Cuba's external economic dependence (1960-2019)}

Three important factors have been constant in the 60 years of the Revolution.

Cuban economic dependency on a foreign nation (Hypothesis 1a). This is a historical fact; during its time as a colony, Cuba was economically dependent on Spain; under the first Republic it was reliant on the United States (68\% of Cuba's total exports); in the first three decades of the Revolution it relied on the Soviet Union ( $72 \%$ of total exports); and since the $21^{\text {st }}$ century Cuba has depended on Venezuela (peak of $44 \%$ of total exports in 2013). Herein Hypothesis $1 a$ is tested regarding the USSR.

In 1960-1990, the USSR granted Cuba $65.119 \mathrm{mln}$ doll. US (trice the aid of president John F. Kennedy's program "The Alliance for Progress" provided to Latin America), an average of $2.170 \mathrm{mln}$ doll. US annually over the period ${ }^{2}$. About $60.5 \%$ of the total economic relationship was in non-repayable price subsidies and showed a rising trend until 1986: The USSR paid as much as twelve times the world market price for Cuban sugar, bought nickel at three times said market price, and Soviet oil exports were sold below the world market price and met $92 \%$ of Cuban fuel needs. Out of the total repayable aid received from the Soviet Union, Cuba repaid only 0.7\% (in 2018 the Russian Federation absorbed the remained debt of mln doll. US and condoned the principal). In the 1980s, Cuba's reached the highest economic indicators under the Revolution; in addition, Soviet aid liberated domestic resources to strengthen Cuban social services that were ahead of most countries in Latin America as well as in socialist countries of Eastern Europe and Asia (Table 1) [Mesa-Lago, 2000].

Table 1. Cuban economic dependency on the URSS 1960-1990 ( $\mathrm{mln}$ doll. US)

\begin{tabular}{|c|c|c|c|c|c|c|c|}
\hline \multirow{2}{*}{ Period } & \multicolumn{3}{|c|}{ Repayable Loans } & \multirow{2}{*}{$\begin{array}{l}\text { Non- } \\
\text { repayable } \\
\text { price } \\
\text { subsidies }\end{array}$} & \multirow{2}{*}{$\begin{array}{l}\text { Total } \\
\text { Aid }^{\mathrm{a}}\end{array}$} & \multicolumn{2}{|c|}{ Percentage distribution } \\
\hline & $\begin{array}{l}\text { Trade } \\
\text { deficit }\end{array}$ & $\begin{array}{l}\text { Develop- } \\
\text { ment }\end{array}$ & Subtotal & & & $\begin{array}{l}\text { Loans } \\
\text { (debt) }\end{array}$ & $\begin{array}{c}\text { Subsidies } \\
\text { (grants) }\end{array}$ \\
\hline $1960-1970$ & 2.083 & 344 & 2.427 & 1.131 & 3.558 & 68.2 & 31.8 \\
\hline $1971-1975$ & 1.649 & 749 & 2.398 & 1.143 & 3.451 & 67.8 & 32.2 \\
\hline $1976-1980$ & 1.115 & 1.872 & 2.987 & 11.228 & 14.215 & 21.0 & 79.0 \\
\hline $1981-1985$ & 4.046 & 2.266 & 6.312 & 15.760 & 22.072 & 28.6 & 71.4 \\
\hline 1986-1990 & 8.205 & 3.400 & 11.605 & 10.128 & 21.733 & 53.4 & 46.6 \\
\hline Total & 17.098 & 8.631 & 25.729 & 39.390 & 65.119 & 39.5 & 60.5 \\
\hline
\end{tabular}

Note. ${ }^{a}$ - military aid (13.400 mln doll. US in the period) and hard-currency revenue in the 1980 s by Cuba reexporting unconsumed subsidized Soviet oil imports.

B as ed on: [Mesa-Lago, 2000].

\footnotetext{
${ }^{2}$ Adjusted for inflation the sum would much higher in 2019.
} 
Due to this enormous level of dependence, the disappearance of the USSR at the start of the 1990s provoked the worst Cuban economic crisis since the Great Depression ( $\mathrm{Hy}$ pothesis 1b): GDP shrunk 35\% in 1989-1993; agricultural-fishing output fell 54\%, nickel output $34 \%$, manufacturing $28 \%$, services $26 \%$, and exports and imports $75 \%$ [Mesa-Lago, 2000]. At its peak in 2012, Venezuelan trade of goods and services accounted for $22 \%$ of Cuba's GDP; the main element of the economic relationship is the barter of Venezuelan oil for Cuban professional services (mainly physicians, but the price paid for them is about seven times the average salary of a Venezuelan physician); later the article shows the adverse effects of the decrease in Venezuela's trade and aid (testing of Hypothesis $1 a$ and $1 b$ regarding Venezuela is done in section 5).

The two adverse factors identified in Hypothesis $2 a$ are:

the economic model. Despite Raúl Castro's structural reforms that in 2007-2018 expanded the non-state sector and the subsidiary market role, the essential characteristics of the model persevere: central planning and state enterprises predominant over the market and private property, a model that has not worked all over the world. Neither the SinoVietnamese model of "market socialism" nor the types of reforms implemented in Eastern Europe (including the Russian Federation) have been followed by Cuba. The new Constitution enacted in 2018 and the new president of the Council of State Miguel Diaz-Canel emphasize continuity;

US embargo/blockade. This started in 1961 and caused an officially estimated cost of US $755.000 \mathrm{mln}$ doll., annually documented by the Cuban government; for many years, virtually all members of the United Nations have condemned the embargo/blockade every year. The Trump administration has tightened the embargo/blockade on investment, tourism, remittances, and oil supply (see section 6).

\section{Cuba's economic performance}

Due to the three persistent factors explained above and despite substantial external economic aid, the Cuban economy has had an unsatisfactory performance (Hypothesis $2 b$ ).

\subsection{Economic growth and gross capital formation}

GDP growth peaked at $12.3 \%$ in 2006 (when Raúl Castro took over power from Fidel) and fell to $1.8 \%$ in 2017. In December 2018, president Díaz-Canel announced a growth rate of $1.2 \%$ for the year, but when ONEI published national accounts in 2019, it doubled the growth rate (Figure 1), making significant revisions to the data: rather than declining by $2.2 \%$, construction jumped $9.3 \%$; agriculture and livestock did not fall $4.9 \%$ but increased $2.6 \%$ and public health rose from $1.3 \%$ to $3 \%$ [Figueredo et al., 2019].

The growth rate target for 2019 is $1.5 \%$, which is deemed unattainable by most experts inside and outside of Cuba because of the impact of the Venezuelan crisis and Trump's punitive measures (see sections 4 and 5). Based on the slowdown in tourist arrivals, reduction in professional services exports, low world market prices for sugar and nickel, Trump's measures, reduction of imported inputs, and a deterioration in the external trade balance, ECLAC projected in July an annual growth for 2019 "close to $0.5 \%$ " and estimated that 26 countries in Latin America and the Caribbean would have growth rates superior to Cuba's [ECLAC, 2019a]. The average annual growth in 2016-2019 (including 


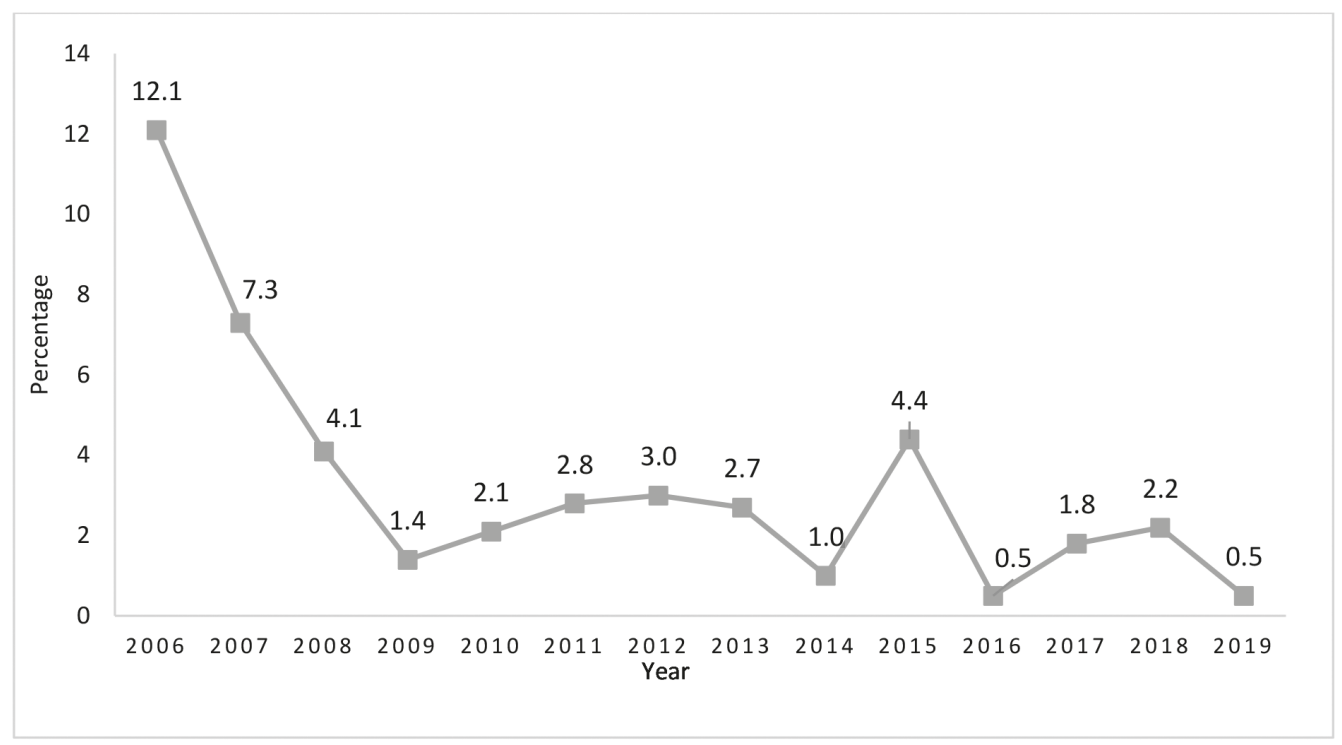

Fig 1. Cuba’s GDP growth, 2006-2019

B as ed on: [ONEI, 2007; 2008; 2009; 2010; 2011; 2012; 2013; 2014; 2015; 2016; 2017; 2018; 2019; ECLAC, 2019].

ECLAC's projection for 2019) is $1.2 \%$, an indication of stagnation and below the growth rate of $5-7 \%$ set by Cuban leaders as essential for appropriate and sustainable development.

The higher gross capital formation (GCF) as a percentage of GDP, the higher the economic growth rate and vice versa. GCF averaged $9.7 \%$ in the last five years (Figure 2), compared to the $25 \%$ that a consensus of Cuban economists considers required for adequate growth rates; the $25 \%$ percentage was achieved in 1989 and it has not come close

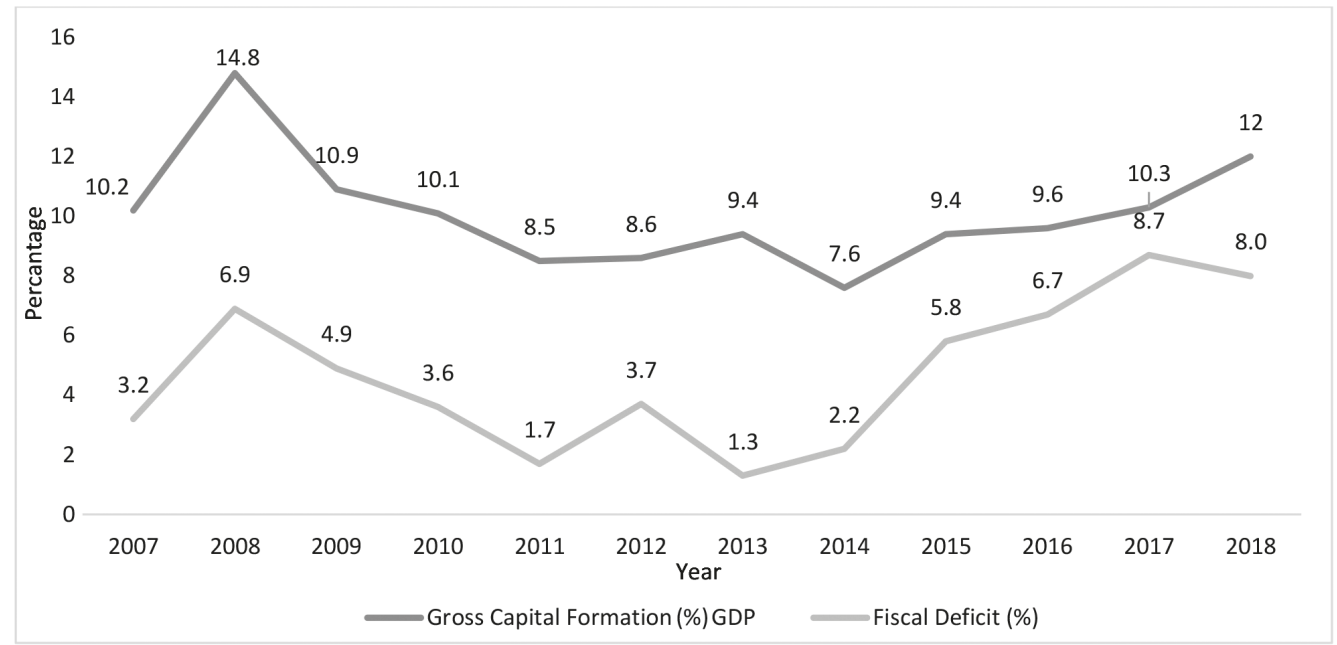

Fig. 2. Cuba's gross capital formation and fiscal deficit, 2007-2018

Based on: [ONEI; 2007; 2008; 2009; 2010; 2011; 2012; 2013; 2014; 2015; 2016; 2017; 2018; 2019]. 
to that rate since then. In 2018, the GCF average in Latin America was $18.7 \%$, about twice the Cuban figure [ECLAC, 2019a].

\section{Fiscal deficit and inflation}

After a decline in 2008-2013, the fiscal deficit rose from $1.3 \%$ of GDP to $8 \%$ in $2013-$ 2017 (Figure 2). ECLAC reports a deficit of $8.8 \%$ in 2018 , four times the regional average of $2.1 \%$; the projected budget deficit in 2018 was $11.5 \%$ but it was lower because expenditures were below the projection [ECLAC, 2019a]. The budget deficit has been financed by public bonds with 20-year maturity sold to the state bank with an annual interest of $2.5 \%$ [Cuba Standard, 2018]. The significant rise in wages in half of the state sector (non-enterprises) in 2019 is forcing to control public expenditures and avoid an increase in the deficit.

Since 1993, the worst year of the 1990 s crisis, when it reached a peak of $26 \%$ of GDP, inflation fell to $0.6 \%$ in 2017 but jumped to $2.4 \%$ in 2018 (Figure 3); there were at least three years with deflation over this period (1995, 2000 and 2016). But official data on the Consumer Price Index (CPI) measuring inflation is not reliable for three reasons: the government sets most prices, which are not determined by the market; the basket of goods and services used to estimate the CPI, as well as their weights, have never been published, so the methodology cannot be checked; and the CPI only includes prices in CUP and excludes prices in $\mathrm{CUC}^{3}$, used by the population to buy a good part of consumer goods at state shops and services sold by the self-employed.

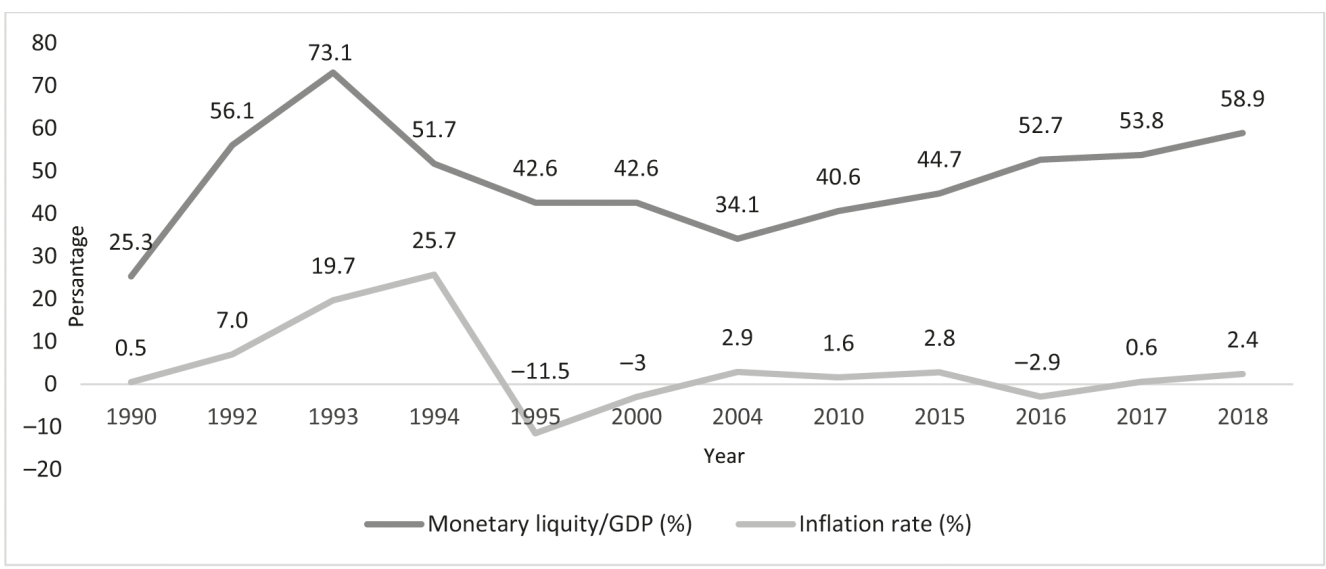

Fig. 3. Inflation rate and monetary liquidity in the population hands, 1990-2018

Based on: [ONEI, 1991; 2001; 2007; 2008; 2009; 2010; 2011; 2012; 2013; 2014; 2015; 2016; 2017; 2018; 2019].

Another indicator of inflationary pressure is monetary liquidity in the hands of the population or monetary surplus (cash in circulation plus bank savings), shown in Figure 3. Said surplus more than doubled in 2007-2018 (from 25.5 to $58.9 \mathrm{mln}$ CUP); as a percentage of GDP, it jumped from $34.1 \%$ to $58.9 \%$. The 2018 figure is the highest since

${ }^{3}$ Two currencies circulate in Cuba: the national peso (CUP) and the "convertible" peso (CUC); the latter is not traded internationally and is fixed by the government. The CUC is valued at par with the dollar and equals 24 CUP. 
the 1993 peak, and also higher than the percentages in 1992 and 1994 . Note that monetary liquidity also excludes prices in CUC. To avoid further inflation, the government has raised funds through public bonds held by state-owned banks, thereby creating a financial bubble; when banks exhaust their ability to buy such bonds, the government will have to resort to monetary emission, which will feed inflation. The interest rate for the bonds is set by the government at $2.5 \%$ below what would be the market rate, meaning that the ministry of finance is receiving funds at subsidized rates [Cuba Standard, 2018]. Inflationary pressure in the second half of 2019 probably rose because of the cited wage increase.

\subsection{Agricultural, cattle and fish production}

Agricultural-cattle output as a percentage of GDP declined from $4 \%$ to $3.6 \%$ in 2007-2017, whereas its rate of annual growth at constant prices receded from $7.3 \%$ to $-1.5 \%$, and averaged $1.8 \%$ per year in the period. The value of agricultural exports decreased $48 \%$ in 2012-2018, but agricultural imports over the same period grew by $17 \%$ and their share in total value of imports rose from $11 \%$ to $17 \%$ [ONEI, 2008; 2009; 2010; 2011; 2012; 2013; 2014; 2015; 2016; 2017; 2018; 2019; Monreal, 2019]. In 2018, Cuba imported $1.929 \mathrm{mln}$ doll. US in agricultural products, $60 \%$ of which could be produced in the country. Raúl Castro's principal agrarian reform was usufruct: transfer of idle state

Table 2. Agriculture, cattle, and fishing output, 1989 and 2009-2018 (thousand metric tons)

\begin{tabular}{|l|c|c|c|c|c|c|c|c|c|c|c|c|}
\hline \multicolumn{1}{|c|}{ Product } & $\mathbf{1 9 8 9}$ & $\mathbf{2 0 0 9}$ & $\mathbf{2 0 1 0}$ & $\mathbf{2 0 1 1}$ & $\mathbf{2 0 1 2}$ & $\mathbf{2 0 1 3}$ & $\mathbf{2 0 1 4}$ & $\mathbf{2 0 1 5}$ & $\mathbf{2 0 1 6}$ & $\mathbf{2 0 1 7}$ & $\begin{array}{c}\mathbf{2 0 1 8} \\
\begin{array}{c}\text { 2018/ } \\
\text { peak } \\
(\mathbf{\%})\end{array}\end{array}$ \\
\hline Tubers & 681 & 1.565 & 1.515 & 1.445 & 1.452 & 1.580 & 1.670 & 1.743 & $\mathbf{1 . 8 4 3}$ & 1.828 & 1.801 & -2 \\
\hline Plantain/banana & 291 & 670 & 735 & 835 & 885 & 658 & 836 & 890 & $\mathbf{1 . 0 1 6}$ & 1.015 & 961 & -5 \\
\hline Vegetables & 610 & $\mathbf{2 . 5 4 0}$ & 2.141 & 2.200 & 2.112 & 2.406 & 2.499 & 2.424 & 2.285 & 2.483 & 2.454 & -3 \\
\hline Rice & $\mathbf{5 3 6}$ & 564 & 454 & 566 & 644 & $\mathbf{6 7 3}$ & 585 & 418 & 514 & 404 & 461 & -32 \\
\hline Corn & $\mathbf{4 7 1}$ & 327 & 324 & 354 & 360 & 426 & 429 & 363 & 404 & 373 & 345 & -26 \\
\hline Beans & 14 & 111 & 80 & 133 & 127 & 129 & 135 & 117 & 136 & 132 & $\mathbf{1 6 1}$ & 0 \\
\hline Citric fruits & $\mathbf{8 2 5}$ & 91 & 345 & 264 & 204 & 167 & 97 & 115 & 119 & 98 & 71 & -91 \\
\hline Other fruits & 219 & 748 & 762 & 817 & $\mathbf{9 6 4}$ & 925 & 884 & 943 & 944 & 926 & 861 & -11 \\
\hline Tobacco leaf & $\mathbf{4 2}$ & 25 & 20 & 20 & 19 & 24 & 19 & 24 & 19 & 31 & 30 & -28 \\
\hline Cow milk & $\mathbf{9 2 4}$ & 600 & 630 & 600 & 604 & 589 & 588 & 495 & 613 & 536 & 577 & -38 \\
\hline Eggs ${ }^{\text {a }}$ & 2.523 & 2.427 & 2.430 & 2.620 & 2.512 & 2.656 & 2.572 & 2.321 & 2.419 & 2.535 & $\mathbf{2 . 7 7 8}$ & 0 \\
\hline Cattle ${ }^{b}$ & $\mathbf{4 . 9 1 9}$ & 3.893 & 3.992 & 4.059 & 4.084 & 4.092 & 4.134 & 4.045 & 4.014 & 3.866 & 3.808 & -22 \\
\hline Fish/seafood & $\mathbf{1 9 2}$ & 65 & 55 & 49 & 48 & 51 & 56 & 57 & 52 & 52 & 51 & -73 \\
\hline
\end{tabular}

Note. Output in 2018 was below the 1989 level [CEE, 1991]; ${ }^{\mathrm{a}}$ - million units; ${ }^{\mathrm{b}}$ - thousand heads; figures in dark font denote the production peak.

Bas ed on: [CEE, 1991; ONEI, 2007; 2008; 2009; 2010; 2011; 2012; 2013; 2014; 2015; 2016; 2017; 2018; 2019$].$ 
land to individual farmers, cooperatives, and state farms for their cultivation, with the government keeping land ownership. Its distribution began in 2008 and, because of its very marginal effects, the law was relaxed in 2012 and in 2018; statistics discussed herein show that usufruct did not increase output.

Table 2 compares the performance of 13 key agricultural, cattle, and fish products in 1989 (the eve of the economic crisis induced by the USSR collapse) and in 2009-2018; output peaks are indicated in bold. Production in 2018 was below the peak in 11 of the 13 products (only grew for beans and eggs), with the decline ranging between $11 \%$ and $91 \%$ in eight of them (rice, corn, citrus, other fruits, tobacco leaf, cow's milk, cattle heads and fish-sea food); for seven products, the 2018 production level was below 1989 (all of the above except other fruits). In contrast, in the period there were notable increases in five products: tubers, bananas, vegetables, beans, and other fruits.

\subsection{Industrial and mining production}

Although there was a clear recovery since 2013, the index of industrial production in 2018 was one-third below the level of $1989,82 \%$ below in sugar and $22 \%$ below in the rest of the industrial sector (Figure 4).

Mining production faded from $0.6 \%$ to $0.5 \%$ of GDP in 2007-2017 [ONEI, 2008; 2009; 2010; 2011; 2012; 2013; 2014; 2015; 2016; 2017; 2018; 2019]. Table 3 exhibits the output of eleven key mining-manufacturing products in 1989 and 2007-2018; the peak production level is denoted in bold. Output dwindled for ten of the eleven products and grew sharply for only two. In 2018, five products were below their 1989 level: sugar, steel, cement, textiles, and fertilizers. In contrast, output increased significantly in oil and natural gas; the former decreased after 2015 due to the exhaustion of wells and the failure of deep-sea oil prospecting, while gas fell after 2015. Nickel grew through 2007 and then

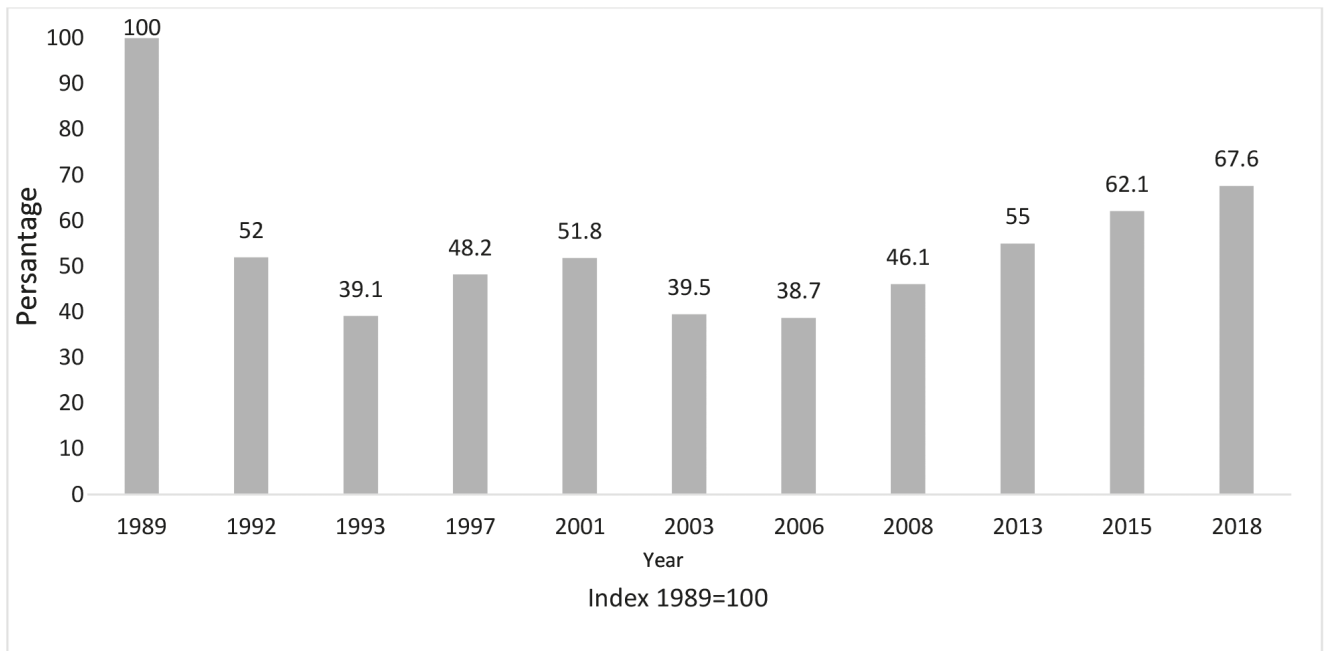

Fig. 4. Index of industrial output, 1989-2018

B as ed on: [CEE, 1991; ONEI, 1998; 2007; 2008; 2009; 2010; 2011; 2012; 2013; 2014; 2015; 2016; 2017; 2018; 2019]. 
Table 3. Mining and manufacturing production, 1989 and 2007-2018 (thousand metric tons)

\begin{tabular}{|c|c|c|c|c|c|c|c|c|c|c|c|c|c|c|}
\hline Products & 1989 & 2007 & 2008 & 2009 & 2010 & 2011 & 2012 & 2013 & 2014 & 2015 & 2016 & 2017 & 2018 & $\begin{array}{c}2018 \\
\text { peak } \\
(\%)\end{array}$ \\
\hline Oil & 718 & 2.905 & 3.003 & 2.731 & 3.025 & 3.012 & 2.998 & 2.897 & 2.905 & 2.822 & 2.619 & 2.522 & $\mathrm{e}$ & -17 \\
\hline $\begin{array}{l}\text { Natural } \\
\text { gas }^{\text {a }}\end{array}$ & 34 & 1.218 & 1.161 & 1.155 & 1.072 & 1.019 & 1.034 & 1.066 & 1.200 & 1.245 & 1.185 & 1.051 & 970 & -22 \\
\hline Nickel & 47 & 73 & 70 & 70 & 70 & 72 & 68 & 55 & 52 & 54 & 51 & 53 & 50 & -27 \\
\hline Sugar & 8.121 & 1.193 & 1.445 & 1.388 & 1.164 & 1.242 & 1.454 & 1.568 & 1.633 & 1.924 & 1.501 & 1.100 & 1.050 & -87 \\
\hline Steel & 314 & 262 & 274 & 266 & 277 & 282 & 277 & 267 & 258 & 221 & 205 & 210 & 188 & -40 \\
\hline Cement & 3.579 & 1.805 & 1.707 & 1.626 & 1.631 & 1.731 & 1.824 & 1.659 & 1.579 & 1.517 & 1.493 & 1.430 & 1.590 & -56 \\
\hline $\begin{array}{l}\text { Elect- } \\
\text { ricity }\end{array}$ & 15.4 & 17.6 & 17.7 & 17.7 & 17.4 & 17.8 & 18.4 & 19.1 & 19.4 & 20.3 & 20.4 & 20.6 & 20.8 & 0 \\
\hline Textiles $^{c}$ & 220 & 24 & 29 & 28 & 25 & 25 & 28 & 34 & 45 & 55 & 55 & 39 & 17 & -92 \\
\hline $\begin{array}{l}\text { Ferti- } \\
\text { lizers }\end{array}$ & 898 & 22 & 40 & 9 & 22 & 39 & 30 & 21 & 32 & 44 & 57 & 72 & 43 & -95 \\
\hline Cigars $^{\mathrm{d}}$ & 308 & 412 & 386 & 375 & 376 & 392 & 392 & 411 & 423 & 412 & 426 & 417 & 280 & -34 \\
\hline $\begin{array}{l}\text { Medi- } \\
\text { cines }\end{array}$ & 78 & 397 & 607 & 639 & 770 & 712 & 713 & 868 & 1.338 & 1.435 & - & - & - & - \\
\hline
\end{tabular}

Note. Figures in bold show the production peak; ${ }^{\mathrm{a}}-$ million cubic meters; ${ }^{\mathrm{b}}-$ thousand Gigawatts $/$ hours $^{\mathrm{c}}{ }^{-}$million square meters; ${ }^{\mathrm{d}}$ - million units; ${ }^{\mathrm{e}}$ - there was a decline of $20 \%$ in the first quarter of 2019.

B a se d on: [CEE, 1991; ONEI, 2007; 2008; 2009; 2010; 2011; 2012; 2013; 2014; 2015; 2016; 2017; 2018; 2019; Torres, 2019; Rodríguez, 2019].

decreased, while cigars increased until 2016 and then declined. Output of medicines grew until 2015; the series was deleted thereafter, which usually indicates a decrease in output.

\subsection{Tourism}

By far, Cuba's best economic performance has been in international tourism, currently the third source of hard currency. In the 1990s, Fidel Castro stimulated tourism; the number of visitors increased 17 times in 1989-2018 (Table 4), and its growth accelerated after 2015, due to the normalization of relations between the United States and Cuba under the Obama presidency, which facilitated visits, air flights and cruises to the island. The average rate of growth of tourists, which in 2015-2017 was $15.7 \%$, dwindled to $1.2 \%$ on 2018 (see causes below); in addition, the total number of tourists decreased $20 \%$ in June 2019 relative to the same month in 2018 and $23 \%$ relative to May 2019 [Perelló, 2019]. Tourism gross revenue (without subtracting the value of imports for the sector) grew at a lower rate than that of visitors in 2007-2018: $29 \%$ and 118\% respectively, because average expenditure per tourist declined $40 \%$ in that period. Since the early 1990 s no data on tourism net revenue had been released; in 2019 the minister of economy and plan- 
ning reported that for every dollar of revenue generated by the tourism industry, more than 60 cents of imports were required [Gil, 2019b]. Using this percentage, net revenue of the tourism industry has been calculated for the entire period (Table 4): in 2018, it was $161 \mathrm{mln}$ doll. US, only $1.1 \%$ of GDP that year and barely double the contribution of nickel to GDP.

Table 4. Indicators of international tourism, 1989 and 2007-2018

\begin{tabular}{|l|l|l|l|l|l|l|l|l|l|l|l|l|l|}
\hline \multicolumn{1}{|c|}{ Indicator } & 1989 & 2007 & 2008 & 2009 & 2010 & 2011 & 2012 & 2013 & 2014 & 2015 & 2016 & 2017 & 2018 \\
\hline $\begin{array}{l}\text { Visitors } \\
\text { (thousands) }\end{array}$ & 270 & 2.152 & 2.348 & 2.430 & 2.532 & 2.717 & 2.841 & 2.855 & 3.006 & 3.532 & 4.036 & 4.654 & 4.712 \\
\hline $\begin{array}{l}\text { Gross } \\
\text { revenue (mln } \\
\text { doll. US) }\end{array}$ & 168 & 2.236 & 2.347 & 2.080 & 2.218 & 2.503 & 2.613 & 2.325 & 2.367 & 2.601 & 2.907 & 3.185 & 2.903 \\
\hline $\begin{array}{l}\text { Net revenue } \\
\text { (mln doll. } \\
\text { US) }\end{array}$ & - & 894 & 939 & 832 & 887 & 1.101 & 1.045 & 930 & 947 & 1.040 & 1.163 & 1.274 & 1.161 \\
\hline $\begin{array}{l}\text { Rooms } \\
\text { (thousands) }\end{array}$ & 21.4 & 47.3 & 49.1 & 60.6 & 65.0 & 66.7 & 65.3 & 65.1 & 66.1 & 66.3 & 67.0 & 73.5 & 84.2 \\
\hline $\begin{array}{l}\text { Occupancy } \\
\text { rate (\%) }\end{array}$ & - & 60.9 & 60.1 & 59.8 & 57.1 & 53.2 & 58.2 & 58.3 & 58.6 & 58.7 & 61.5 & 56.9 & 49.5 \\
\hline $\begin{array}{l}\text { Average } \\
\text { expense per } \\
\text { tourist (doll. } \\
\text { US) }\end{array}$ & 622 & 1,039 & 998 & 856 & 875 & 921 & 1.087 & 814 & 787 & 736 & 720 & 684 & 616 \\
\hline
\end{tabular}

Note. ${ }^{\text {a }}$ - Estimated as $40 \%$ of gross revenue, based on the $60 \%$ official figure of imports in 2018 .

B a sed on: [CCE, 1991; ONEI, 2007; 2008; 2009; 2010; 2011; 2012; 2013; 2014; 2015; 2016; 2017; 2018; 2019 ].

The number of hotel rooms doubled in 1989-2007, and rose $78 \%$ in $2007-2018$. The percentage of rooms managed by the private sector grew to $36 \%$ of the total in 2019 , its share of gross income to $22 \%$ and its growth rate was $18.5 \%$ in 2018 compared with $3.8 \%$ in the state sector [Perelló, 2018; ONEI, 2008; 2009; 2010; 2011; 2012; 2013; 2014; 2015; 2016; 2017; 2018; 2019; Herrera, 2019]. Recently, the tourist infrastructure has been expanded with the construction of five-star hotels in Havana, including the Kempinski's "Gran Manzana" with rates as high as 1,000 doll. US per night [AFP, March 11, 2019]. Meanwhile average occupancy decreased 11 percentage points in 2007-2018 (Table 4). Also descending are average days of stay (-59\% in 1989-2017) and daily revenue ( $-23 \%$ in 1997-2016), whereas hotel losses have increased [Herrera, 2019; Romeo, 2019]. In view of these state-sector indicators, several Cuban economists have questioned the official strategy of expanding hotel construction and investment in tourism (4000 rooms and $3 \mathrm{mln}$ doll. US in 2019, respectively) and have suggested focusing on quality rather than quantity.

Foreign tourists in 2018 came mostly from Canada (24\%), the USA (14\%), CubanAmericans (13\%), and between $3 \%$ and $4 \%$ Italian, German, Russian, French, English, and Spanish. The number of US tourists grew $590 \%$ in 2014-2018, due to the thaw of relations between Cuba and the U.S., and this also pushed upward the trend from all emitting 
countries until 2017. In the fourth quarter of 2017 and the first half of 2018, there was a decrease in tourism (208.296 fewer) for three reasons: damage to infrastructure caused by hurricane Irma in September 2017 particularly to facilities in the North Coast Cays; the ban by the Trump administration affecting US tourists staying at hotels and eating at restaurants run by the military; and the US government's alert not to travel to Cuba because of the danger of sonic attacks that arguably affected diplomats. In 2018 Canadian and European visitors declined and Americans grew but at a much slower pace; only CubanAmericans increased substantially [ONEI, 2007; 2008; 2009; 2010; 2011; 2012; 2013; 2014; $2015 ; 2016 ; 2017 ; 2018 ; 2019]^{4}$. The government target for 2018 was $5.1 \mathrm{mln}$ tourists but in September it was reduced to 4.8 million and the final figure was $4.7 \mathrm{mln}$. Cruise tourists accounted for $45 \%$ of total arrivals in 2018 and rose to $53 \%$ in the first half of $2019^{5}$. After June, when Trump's suspension of cruise ships started, arrivals declined 15-20\% [Marrero, 2019; Perelló, 2019]. In January - October 2019, the number of tourists had declined by $303,920,8 \%$ less that in the same period of 2018 ; U. S. tourists decreased $13 \%$ and even worst declines occurred on Western-European visitors [ONEI, 2019].

The initial plan for 2019 was for tourists to exceed 5 million tourists [Fuentes, 2018]. By the end of the first semester, the number of visitors had been revised to 4.3 million tourists for the entire year, which would be impossible to achieve in view of the October figures.

\section{Cuba's dependency on Venezuela and effects of its crisis}

This section ${ }^{6}$ tests Hypothesis $1 a$ and $1 b$ pertaining to Venezuela. Throughout the revolution, there has been a systematic deficit in Cuba's trade balance of goods [Pérez-Lopez, 2017]. Such a deficit reached a historical zenith of 10,400 mln doll. US in 2008 and then declined: while exports steady dropped after 2011, imports were cut also. Exports and imports peaked in 2011: in 2018, exports of goods were $49 \%$ below their 1989 level and $56 \%$ below their 2011 level, while imports increased by $41 \%$ and decreased by $18 \%$, respectively. Consequently, the merchandise deficit in 2018 grew by $220 \%$ compared to 1989 and $11 \%$ relative to 2011 (Table 5). Monetary and exchange rate duality are serious obstacles to increase exports because their distortions impede identifying profitable exports.

\subsection{Exports of professional services to Venezuela}

Starting in the $21^{\text {st }}$ century, Cuba began exporting professional services (mainly doctors, nurses, and teachers) based on a treaty with Venezuela, the buyer of about $75 \%$ of those services. As a result, there was a surplus in the balance of services trade that not only offset the goods trade deficit, but generated a surplus in the overall balance of trade of goods and services (except in 2008 because of the huge deficit in goods) that reached a peak in 2014. Due to Venezuela's severe economic crisis, the aforementioned surplus decreased by $51 \%$ in 2014-2018. Table 5 calculates the value of Cuba's professional services

\footnotetext{
${ }^{4}$ Russian tourists grew $12 \%$ in 2018 but their participation is less than $3 \%$ of the total [ONEI, 2008; 2009; 2010; 2011; 2012; 2013; 2014; 2015; 2016; 2017; 2018; 2019].

${ }^{5}$ Cruise tourists spent $15 \%$ of the amount spent by visitors arriving by air, contributing to the declining trend in daily expenses.

6 This section is mainly based on [Mesa-Lago,Vidal, 2019; ONEI 2019].
} 
Table 5. External balance of goods and services, 1989 and 20072019 ( $\mathrm{mln}$ doll. US, current prices)

\begin{tabular}{|c|c|c|c|c|c|c|c|c|c|c|c|c|c|}
\hline $\begin{array}{c}\text { Goods } \\
\text { and } \\
\text { ser- } \\
\text { vices }\end{array}$ & 1989 & 2007 & 2008 & 2009 & 2010 & 2011 & 2012 & 2013 & 2014 & 2015 & 2016 & 2017 & 2018 \\
\hline \multicolumn{14}{|l|}{ Goods $^{\mathrm{a}}$} \\
\hline 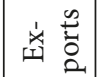 & 5,400 & 3,966 & 3,940 & 3,020 & 4,754 & 6,170 & 5,899 & 5,566 & 5,149 & 3,572 & 2,546 & 2,704 & 2,742 \\
\hline 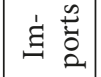 & 8,139 & 10,118 & 14,312 & 8,938 & 10,689 & 14,019 & 13,869 & 14,773 & 13,101 & 11,745 & 10,302 & 10,212 & 11,527 \\
\hline 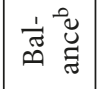 & $-2,739$ & $-6,152$ & $-10,372$ & $-5,918$ & $-5,935$ & $-7,849$ & $-7,970$ & $-9,207$ & $-7,952$ & $-8,173$ & $-7,756$ & -7.508 & $-8,785$ \\
\hline \multicolumn{14}{|c|}{ Services } \\
\hline 离营 & - & 7,952 & 8,566 & 7,819 & 9,765 & 11,149 & 12,760 & 13,027 & 12,663 & 11,369 & 11,144 & 11,379 & 11,764 \\
\hline 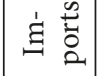 & - & 215 & 494 & 656 & 711 & 1,060 & 1,019 & 829 & 764 & 860 & 924 & 1,098 & 1,042 \\
\hline 寻 & - & 7,732 & 8,072 & 7,163 & 9,054 & 10,089 & 11,741 & 12,198 & 11,899 & 10,509 & 10,222 & 10,281 & 10,722 \\
\hline 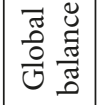 & - & 1,585 & $-2,300$ & 1,901 & 3,119 & 2,240 & 3,771 & 2,991 & 3,947 & 2,336 & 2,464 & 2,774 & 1,937 \\
\hline 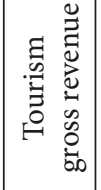 & - & 2,236 & 2,346 & 2,082 & 2,218 & 2,503 & 2,613 & 2,607 & 2,546 & 2,819 & 3,069 & 3,302 & 2,903 \\
\hline 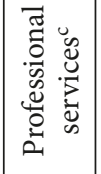 & - & 5,716 & 6,220 & 5,737 & 7,547 & 8,646 & 10,147 & 10,420 & 10,117 & 8,550 & 8,075 & 8,077 & $8,861^{\mathrm{d}}$ \\
\hline 猋 & - & 9.8 & 10.2 & 9.2 & 11.7 & 12.5 & 13.8 & 13.5 & 12.5 & 9.8 & 8.8 & 8.3 & 8.8 \\
\hline
\end{tabular}

Note. ${ }^{\text {a }}$ - Official figures are given in "pesos» without specifying if in CUP or CUC; there is a consensus that they are in CUC similar to the US dollar; ${ }^{\text {b }}$ - [ONEI, 2019] (table 8.3) gives a different series of the trade balance of goods with a higher deficit than in table 5.13 hence the global balance is smaller; ${ }^{c}$ - exports of services less gross revenue from tourist services; ${ }^{\mathrm{d}}$ - ONEI gave for the first time the value of exports of services distributed by type for 2018 (see estimates of professional services in the text) [ONEI, 2019].

B a sed on: author's elaboration 1989 from [CCE, 1991; 2007; 2008; 2009; 2010; 2011; 2012; ONEI, 2007; 2008; $2009 ; 2010 ; 2011 ; 2012 ; 2013 ; 2014 ; 2015 ; 2016 ; 2017 ; 2018 ; 2019]$. 
exports (subtracting the value of tourist revenue from total service exports): professional exports declined by $22 \%$ in 2013-2017 (with an uptick in 2018), which is a major cause of the GDP decline from $7.3 \%$ to $2.2 \%$ in 2007-2018 [ONEI, 2008; 2009; 2010; 2011; 2012; $2013 ; 2014 ; 2015 ; 2016 ; 2017 ; 2018 ; 2019]$. For the year 2018, ONEI revealed for the first time the value of total services exports distributed by type [ONEI, 2019]. The combination of human health and social care, education, other professional and technical services, and cultural and sports ${ }^{7}$ amounted to $6.700 \mathrm{mln}$ doll. US.

Bolivia, Brazil and Ecuador changed their governments and ended purchases of 9.624 Cuban physicians, an annual loss of about $1 \mathrm{mln}$ doll. US [Revelan cuanto Cuba..., 2019; Ecuador ends..., 2019; Cuba withdraw..., 2019]. Angola and Algeria have reduced them, Mozambique revoked the exchange agreement, and the relationship with Kenya is in jeopardy. Despite those setbacks, professional services mainly from Venezuela remain Cuba's main source of foreign exchange, their contribution to total exports (goods and services) rising from $56 \%$ to $61 \%$ in 2013-2018, albeit at a reduced value (Table 5).

\subsection{Venezuelan oil supply}

Venezuela's oil exports to Cuba have wilted considerably. At its peak in 2012, Venezuela exported 105 oil barrels per day (b/d) to Cuba, but supply dropped to $55.000 \mathrm{~b} / \mathrm{d}$ in 2017 and $40.000 \mathrm{~b} / \mathrm{d}$ in January — May 2019. In addition, PDVSA purchased $400 \mathrm{mln}$ doll. US of Russian oil that was delivered to Cuba between January 2017 and May 2018. Total Cuban imports of fuels, lubricants and derivatives decreased by $69 \%$ in 2007-2017, while Venezuelan imports dwindled by $67 \%$. Compounding this problem, Cuban crude oil production in thousand metric tons decreased from a peak of 3.025 in 2010 to 2.522 in 2017; no data is available for 2018 [ONEI, 2013; 2018]. Thus, the reduction in fuel imports coincided with the drop in domestic production; it has been estimated that Cuba faces a deficit of $65,000 \mathrm{~b} / \mathrm{d}$ of oil that has prompted a program of austerity and cuts in energy supply for businesses [Piñón, 2019].

\subsection{Venezuelan subsidies to the price of Cuban professional services}

Under the agreements with Venezuela, Cuba pays for the import of oil and its derivatives with the sale of professional services. But the price of those services has been inflated (the Cuban state was paid for one of its doctors seven times what a Venezuelan doctor was paid, on average), so there was a significant subsidy in disguise. In addition, a considerable amount of crude oil from Venezuela was processed at the refinery in Cienfuegos, with the refined products forwarded to Venezuela; this business generated some excess production of refined oil products that Cuba exported for a juicy foreign exchange gain (as it did with the USSR). The supply of oil to be refined in Cuba was halved in 2016, reducing the refined amount and exports. Venezuela is estimated to have lost a potential oil revenue of $29.4 \mathrm{mln}$ doll. US in its barter with Cuba in 1996-2017.

7 "Health and social care services" account to $57 \%$ of total services, while "educational services" are only $2 \%$ and the rest represent even smaller shares. 


\subsection{Direct investment from Venezuela}

In 2001-2014, the Intergovernmental Commission of the two countries approved 475 Venezuelan investment projects in Cuba worth 8,000 mln doll. US. In addition, Venezuela's Economic and Social Development Bank allocated 1,500 mln doll. US to finance projects in 2007-2010, while the Autonomous Fund for International Cooperation provided close to $1 \mathrm{mln}$ doll. US in loans to Cuban companies. While some of these projects were not carried out and apparently disappeared after 2014, Venezuela's direct investment has been significant, especially the Cienfuegos refinery.

\subsection{Value of Cuba's total economic relationship with Venezuela and its components}

Figure 5 shows the total value of the Cuba-Venezuela's relationship, its composition and trends in 2007-2017 (no data are available for 2018). The total value peaked at $16.017 \mathrm{mln}$ doll. US in 2012 and declined by one half in 2017. All the components declined between the peak and 2017: exports of professional services by $30 \%$, fuels by $70 \%$ and non-oil trade by $85 \%$.

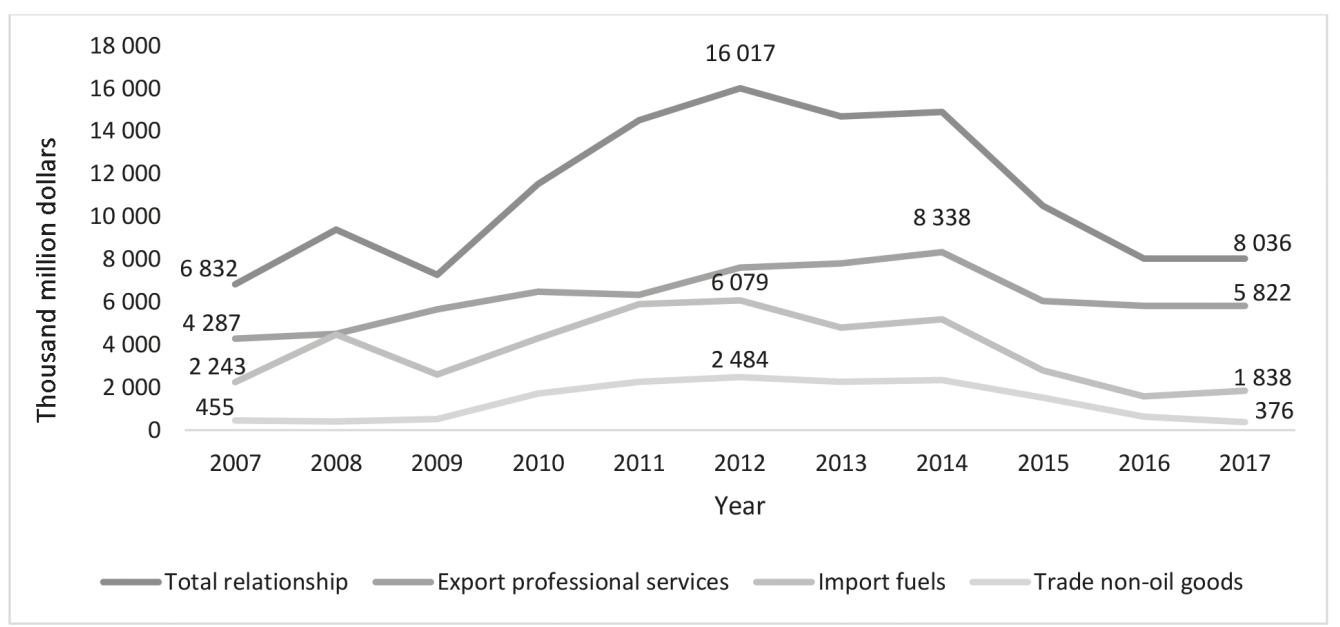

Fig. 5. Economic relationship Cuba-Venezuela, 2007-2017 (mln doll. US)

Bas ed on: [ONEI, 2007; 2008; 2009; 2010; 2011; 2012; 2013; 2014; 2015; 2016; 2017; 2018; 2019].

In terms of GDP, the value of the economic relationship peaked at $22 \%$ in 2012 and declined to $8 \%$ in 2017, a decrease of 14 percent (Figure 6).

\subsection{Potential effects of a total cut in Cuba's relationship with Venezuela}

A fall of the current Venezuelan political regime or a collapse of its economy would have a severe impact on Cuba's economy updated with recent data, based on [Mesa-Lago, Vidal, 2019]: 


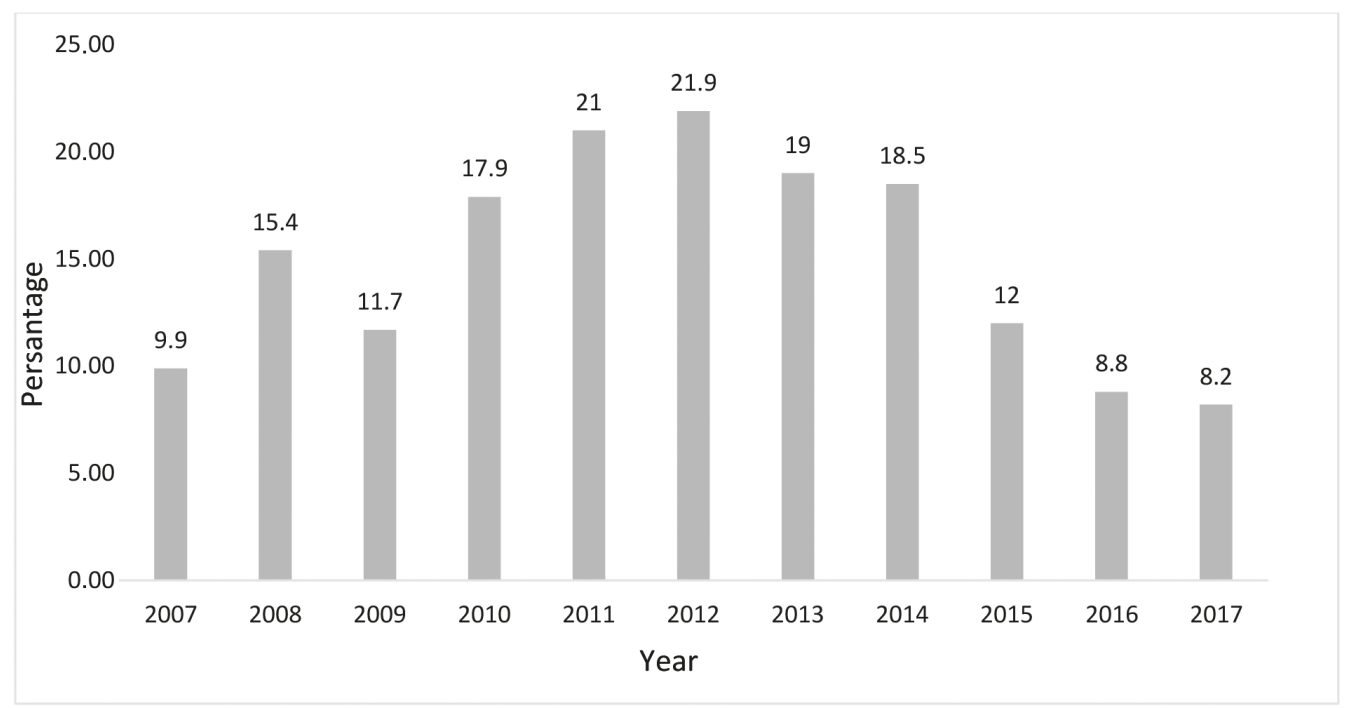

Fig. 6. Economic relationship Cuba-Venezuela as percentage of Cuba's GDP, 2007-2017

B a sed on: see Figure 6 and GDP from [ONEI, 2007; 2008; 2009; 2010; 2011; 2012; 2013; 2014; 2015; 2016; 2017; $2018 ; 2019]$.

a) a loss of an economic relationship estimated at 8,000 mln doll. US annually;

b) a significant drop in exports of professional services (professionals returning from Venezuela to Cuba would have to be provided jobs, otherwise, open unemployment would rise);

c) a loss of about 1,800 mln doll. US in oil supplies at favorable financing terms;

d) a deficit in the balance of payments, the halting of payments on the restructured debt, a worsening of defaults to foreign suppliers that would make it even more difficult to access foreign credit;

e) a harsh cut in imports that would have an adverse effect on industry and agriculture, thus worsening current food and consumer goods scarcities;

f) electricity blackouts affecting the population, interruption of work at factories, and transportation problems;

g) a serious retreat of the private sector;

h) two-digit inflation arising from significantly rising monetary liquidity to levels similar or close to those in 1993 ;

i) a depreciation in the exchange rate; and

j) a decline in GDP in the range of $5 \%$ to $7 \%$.

\section{Trump's punitive sanctions against Cuba and their effects}

Hypothesis $2 a$ stated that the Cuban economy has further suffered due to the punitive sanctions imposed by Donald Trump, both against Venezuela and Cuba [Mesa-Lago, Vidal, 2019]. 


\subsection{Tourism}

We have noted measures taken to cut US tourism to Cuba. The US Executive compiled a list of restricted Cuban entities out of limits for American tourists that included military and intelligence agencies; the list has been expanded twice and now includes some 200 entities. These restrictions prompted US airlines to eliminate 2.574 flights, and flight occupancy declined from $61.3 \%$ to $52.4 \%$ between January-September 2017 and the same period in 2018. In June 2019, all travel to Cuba save for family purposes was banned, including via cruises, yachts and flights by private and corporate airplanes, as well as educational and "people-to-people" travel authorized by Obama in 2016 [United States, 2019]. As most US tourists arrived by cruises and most air travelers used people-to-people tours, this is the second most damaging measure imposed by Trump; his sanctions may cost Cuba $1.383 \mathrm{mln}$ doll. US [Prensa Latina, November, 2019]. Private micro-businesses have been affected by the drop in U.S. visitors [Mojena, 2019].

\subsection{Venezuela's oil supply to Cuba}

In March 2019, Trump decreed a halt in shipments of Venezuelan oil to Cuba. Former US National Security Adviser John Bolton warned ship insurance companies that Washington would enforce such order. In July, the Treasury Department sanctioned Cubametales (Cuba's state oil importer) as well as two foreign transport companies and blocked ownership of 34 Venezuelan oil agency (PDVSA) tankers, as well as two companies based in Liberia and Greece. As there are 4.5 oil tankers globally, enforcement through banning individual ships is complicated: just after the sanctions were announced, Maduro sent one million barrels of oil to Cuba on two ships and the Venezuelan foreign minister declared that his country will honor its oil commitments to Cuba. Several oil tankers have been renamed to avoid the sanctions and others have delivered oil incognito [Kassai, Bartenstein, 2019]. In September 2019, new measures were imposed against several oil tankers, some of them based in Cyprus and Panama [OFAC, 2019]. Trump also ordered the seizure of revenue from Venezuelan oil sales in the USA, but Caracas diverted those exports to other countries and transferred the accounts of its oil companies to the Russian bank Gazprombank ${ }^{8}$. Because of cuts in oil supply, some cement factories have reduced output, a steel mill stop production temporarily, several hotels constructions in Havana have sent workers home, and state offices, universities and schools have cut hours; gas stations have long lines (Reuters, October 2, 2019).

\subsection{Strengthening sanctions on international banks that do business with Cuba}

In late 2018, the Federal Reserve Bank imposed a fine of 1,340 mln doll. US on Societé General for violations of US sanctions against Cuba; also sanctioned have been PostFinance, Standard Chartered (947 mln doll. US), Unit Credit (1.3 mln doll. US) and Paribas

${ }^{8}$ On October 28, 2019, Venezuela's oil agency abroad (Citgo) must pay $913 \mathrm{mln}$ doll. US to bondholders; if there is a default, Citgo may be seized by its creditors, including Russian oil company Rosneft [Krauss, 2019]. On October 25, the US Treasury Department may decide to end a license to U.S. oil company Chevron to continue its operations in Venezuela worth 2,700 mln doll. US; if that happens, Chevron must shut down and the Venezuelan government may transfer its share to a Russian company [Delgado, 2019]. 
(8.9 mln doll. US). In 2019, Panamanian Multibank closed multiple bank accounts of Cuban companies with which it had had transactions [Frank, 2019; Bancos extranjeros..., 2019]. Fines were also levied on financial transactions ("U-turn") in dollars by international banks, in which the Cuban government or citizens receive funds transferred from abroad. These punitive measures make it extremely difficult for the island to do transactions with foreign banks and nearly impossible to obtain private credit.

\subsection{Foreign investment}

In March 2019, Trump ordered starting in May the application of Title III of the Helms-Burton Act, authorizing US citizens to sue in US courts Cuban companies (registered in the cited list of companies controlled by Cuban military or intelligence agencies) that "profited" from property confiscated by the Cuban government from their owners (that title had been suspended every six months from Clinton to Trump). Affected foreign companies are from Canada, Spain, France, Mexico, the United Kingdom, and even US airlines and cruise ships. Also, based on Title IV of the Helms-Burton law, the State Department was ordered to deny US visas to foreigners who traffic in property confiscated by Cuba or executives or shareholders of companies that have conducted such activities. There are 5.913 certified lawsuits worth $1.9 \mathrm{mln}$ doll. US; adding accrued interest the amount of the claims rose to nearly $8,000 \mathrm{mln}$ doll. US. The application of Title III could lead to filings regarding some 200.000 uncertified claims worth tens of thousands of millions and would pack US courts (several already have been sued). The European Union and Canada have announced that they will use all potential legal avenues to impede the application of Title III against their nationals, including a demand to the WTO and countersuits against those presented in US courts. According to [ECLAC, 2019] the application of Title III represents an important disincentive to attract new flows of direct foreign investment, a flow that already is low. Although the more than one hundred existing investors apparently are staying the course, some big corporations have fled and potential investors are evaluating the totality of risks involved in doing business with Cuba, while yet others are postponing their decision until the results of the 2020 presidential elections are known [Frank, 2019]. The Helms-Burton sanctions have the potential to be the most impactful toward Cuba due to the island's need to generate $2.5 \mathrm{mln}$ doll. US annually in foreign investment.

\subsection{Foreign remittances}

The amount of remittances, mainly sent from the Unites States, rose from 1,400 mln doll. US in 2008 to $3,700 \mathrm{mln}$ doll. US in 2018; they are the second most significant source of hard currency [Morales, 2019]. In April 2019, former National Security Adviser Bolton announced that such remittances will be limited to 1 doll. US per person quarterly, half the 2 doll. US per-quarter limit imposed by President George W. Bush in 2004 and later abolished by President Obama. This measure probably will not have a very strong impact for two reasons: remittances could be sent by several people in the USA, for example, a group of family members, to the same individual in the island, a trick that was used to circumvent Bush's remittances cap; and most Cubans abroad do not send such a high level of remittances. However, the cap could affect micro-entrepreneurs on the island many 
of whom have plans to establish or expand their activities counting on money sent from abroad by partners, relatives or friends (in September 2019, the US government exempted micro-entrepreneurs from the cap).

\subsection{Other current and potential negative sanctions}

In October, the US Department of the Treasury cancelled licenses for renting Cuban air and sea vessels, banned exportation to Cuba of products that have more than $10 \%$ of $U$ $S$ components, and terminated US donations to Cuba that may end in government hands [Pentón, 2019]. In addition, Trump has threatened to return Cuba to the list of state sponsors of terrorism, from which Obama pulled it in 2015, after being so listed since 1982 . Trump also stated in April 2019: "If Cuban troops and militias do not immediately cease military and other operations with the purpose of causing death and destruction to the Constitution of Venezuela, a full embargo will be imposed on the island of Cuba, along with sanctions at the highest level". For his part, US Secretary of State Pompeo warned that "military action is possible and if that is required, the United States will take such action" [Casey, 2019; Rogers, 2019].

\subsection{The magnitude of the ongoing crisis and that of the 1990s crisis}

The combination of the Venezuelan crisis and Trump's sanctions are already causing significant damage to the Cuban economy, which would worsen if Venezuela's political regime were to fall or the economic deterioration deepen. Despite the worrying effects analyzed above, however, as posed in Hypothesis 3, the crisis in Cuba probably would not be as strong as that in the 1990s because of changing conditions (see Table 6): more diversified trade partners; lower main-partner share of Cuba's total trade deficit; higher and more diversified foreign investment; much higher hard-currency revenue from tourism; considerably more foreign remittances; lower dependency on imported fuels; a much bigger private sector; and lower overall economic dependency.

All the above factors, however, may be shaken by Trump's sanctions. In addition, Cuba in 1985-1989 had its best economic-social performance, whereas now the economy is in its worse situation since the 1990s. The crisis would be politically more difficult to manage because Fidel Castro is gone and Raúl Castro's structural reforms raised high expectations that they would improve the economy and living standards, which did not materialize.

\section{The probability of either Russia or China replacing Venezuela}

Hypothesis 4 sustains that there is a low probability that either the Russian Federation or the Peoples' Republic of China will fully replace Venezuela, although these two countries could help Cuba with trade and economic aid, as explained below.

In 2018 the Russian Federation was Cuba's seventh trading partner, its trade of goods reached $3.3 \%$ of the total, its deficit in the trade balance of goods amounted to $430 \mathrm{mln}$ doll. US, the largest since the Russian Federation was created (Cuba imported $440 \mathrm{mln}$ doll. US and only exported $11 \mathrm{mln}$ doll. US) and Russia does not buy Cuban professional 
Table 6. Comparison of Cuba's economic dependence on the USSR and Venezuela

\begin{tabular}{|l|c|c|}
\hline \multicolumn{1}{|c|}{ Factors in the economic dependence } & $\begin{array}{c}\text { USSR } \\
\text { 1987-1989 }\end{array}$ & $\begin{array}{c}\text { Venezuela } \\
\mathbf{2 0 1 8}\end{array}$ \\
\hline Greater diversification in commercial partners (\% of trade volume) & 72 & 29 \\
\hline Lower concentration of the trade deficit (\% of total deficit) & 82 & 28 \\
\hline Higher diversity in foreign investment (mln doll. US) & $1^{\text {a }}$ & $7,676^{\text {b }}$ \\
\hline Higher hard-currency exports of professional services (mln doll. US) & 0 & 8,861 \\
\hline Higher hard-currency revenue from tourism (mln doll. US) & 168 & 2,903 \\
\hline Higher hard-currency revenue from remittances (mln doll. US) & 0 & 3,500 \\
\hline Less dependence on imported fuels (\% of total) & 92 & 60 \\
\hline Bigger private sector (\% of labor force) & 6 & 26 \\
\hline Overall dependence (\% of GDP) & 28 & 8 \\
\hline
\end{tabular}

Note. ${ }^{\text {a }}$ - The USSR was the only investor, although for some projects there were associations with Eastern European partners. It was not possible to estimate the amount of Soviet investment; ${ }^{\mathrm{b}}$ - this information refers to all projects [DíazCanel, 2019b], but in the Mariel Special Development Zone (ZEDM), while some 400 proposals have been mentioned, only 43 foreign investment projects seem to have crystallized, 19 projects already in operation and 23 in process of approval, for a cumulative $2.1 \mathrm{mln}$ doll. US in the six years since the creation of ZEDM, vis-à-vis a target of $15 \mathrm{mln}$ doll. US for the period [Pérez Villanueva, 2019]. Besides, this information provided to the author from E. Morales by e-mail, August 30.

B a s e d on: USSR from [Mesa-Lago, 2000], Venezuela from [ONEI, 2009; Mesa-Lago, Vidal, 2019].

services. However, in 2017 the trade of goods with Russia had risen 95\%, after a four-year decline and stagnation - the increase was only $20 \%$ over 2007 [ONEI, 2019]. In November 2018, Havana signed several agreements with Moscow concerning: modernization of electricity production and steel; rail transport; exploration of bituminous oil deposits; and recovery of citrus production. The amounts of these projects were unknown and several of them had been agreed before. Early in October 2019, Russian Prime Minister Dmitrii Medvedev visited Cuba and signed eight agreements - some of them related to the previous ones - providing some data on the amounts: renovation of the railroad system including selling 75 locomotives -51 has been delivered already (2,000 mln doll. US, but $200 \mathrm{mln}$ doll. US by 2020); oil prospecting in land by Russian company Zarubezhneft (100 mln doll. US), application of atoms to medicine in agriculture (not energy), and selling military equipment ( $43 \mathrm{mln}$ doll. US) (Granma, editions 7 to 18 October 2019). The revealed sums of short-term aid total $343 \mathrm{mln}$ doll. US; although this aid is important to Cuba at this difficult juncture, it accounts to $14 \%$ of the $2,500 \mathrm{mln}$ doll. US in foreign investment that the island needs annually and to $4.3 \%$ of the $8,000 \mathrm{mln}$ doll. US provided by Venezuela. Russia has supplied oil to Cuba, but partly paid for by Venezuela. It is virtually impossible for Cuba to pay for the value of Russian imports because, as have been proven herein, production of sugar, nickel, citrus, tobacco and fisheries - which constituted Cuban exports to the USSR in the 1980s - have declined sharply, and it is unlikely that Cuba will compensate Russian oil with exports of doctors and other professionals, who would have to learn the language. In addition, Venezuela pays Cuban doctors up to seven times 
more than an average Venezuelan doctor. Finally, Russia's current economic slowdown makes it harder for her to fully replace Venezuela.

China could be another potential replacement: it is Cuba's second trading partner, with a $16 \%$ share in total goods trade, but in 2018 said exchange was $1 \%$ below the 2017 level and $23 \%$ below the 2016 level. The trade deficit with China was $1.088 \mathrm{mln}$ doll. US (Cuba imported $1.544 \mathrm{mln}$ doll. US and exported only $456 \mathrm{mln}$ doll. US), tantamount to $23 \%$ of Cuba's total trade deficit, the largest after Venezuela's [ONEI, 2019]. Relations between Beijing and Havana have strengthened in recent years, with an agreement signed in 2017 worth $164 \mathrm{mln}$ doll. US to acquire Chinese construction equipment and a $129 \mathrm{mln}$ doll. US donation for cybersecurity. However, these sums are minute when compared to huge Chinese investments in Latin America, especially in large countries that produce raw materials needed by China. By contrast, Cuba has virtually no products to export to China - except 400.000 tons of sugar that must be sent annually - and it is even more difficult for it to export professional services, for language and cultural reasons. Finally, China is going through a period of slowing economic growth - the 2018 growth rate was the lowest since 1990 - and Trump's rise in tariffs also has an adverse effect on the Chinese economy in 2019. It seems unlikely therefore that China could fully replace Venezuela.

\section{Cuban government strategies and policy alternatives}

Raúl Castro's economic reforms in 2007-2017 were well oriented but too slow, not deep enough, and subjected to many restrictions, disincentives and taxes; because of those factors said reforms did not achieve an economic improvement as shown in section 3 [Mesa-Lago, 2018; Mesa-Lago et al., 2018]. In his closing speech to the National Assembly in April 2019, Raúl Castro warned: "We have to be alert and aware that we face additional difficulties and that the situation could worsen in the coming months (due to the crisis in Venezuela and Trump's policies), even if it is not returning to the situation of the special period in the 1990s, because today we have another panorama in terms of the diversification of the economy. But we have to prepare ourselves for the worst scenario".

President Miguel Díaz-Canel has promised continuity, which is incongruous to confront the deteriorating Venezuelan economy, Trump's punitive measures and the absence of countries capable and willing to replace Venezuela. The strategy adopted by Cuban legislators in April 2019 was more long- than short-term, for instance: one of the targets of the 2030 plan is to secure 30 pounds of tubers, vegetables, beans and fruit per day to the population. The long-term plan to 2030 is divided in three stages: 2019-2021, 2022-2026 and 2027-2030, but no details have been given for each of these stages. It is vaguely said that the 2019-2021 stage will set the bases for future transformations through advances such as the implementation of a new management and administration model. The measures announced for 2020 (not for 2019) are also imprecise, such as to concretize projects for increasing exports, to incorporate into the plan investments that stimulate oil extraction, to seek new product lines to replace imports, and to ensure the production of goods and services that meet domestic demand, food in particular. The plan reiterated old unsuccessful policies and goals, and continued to place emphasis on the central plan and state enterprises as the key economic tools, with little mention of the necessary acceleration and deepening of the reforms.

Economics Minister Gil [Gil, 2019a] identified six strategic sectors that are key to confront the looming crisis: tourism, biotechnology-pharmaceuticals, food production, 
electricity and energy, exports of professional services and construction. According to him, the growth in exports in the six cited activities (especially in the first three) represent more than $90 \%$ of the projected export increases by 2030 and $65 \%$ of the replacement of imports projected for that year. However, Gil acknowledged that exports do not grow with the required dynamism, foreign investment levels are low and poor use of energy products and non-compliance with the import plan persist. He added that internal measures (belt tightening) would need to be employed.

Several Cuban economists pointed out problems in the government strategy: the huge and urgent problems that Cuba faces; a response marred by excessive caution, and lack of imagination, daring and quickness to confront the challenges; the absence in the discussion of the long-standing, broad consensus on needed economic reforms; the absence in the plan of policies regarding the private property and micro-enterprises which should be given priority; and the widespread scarcity of essential food items [Mesa-Lago, Vidal, 2019].

Perhaps prompted by the above reactions or by the realization of the magnitude and urgency of the crisis, in June 2019 Díaz-Canel announced new policies, the most concrete and widely discussed being the increase by $37 \%$ in the wages of employees in the budgeted sector of the economy, as well as of pensions. The Cuban president also acknowledged important economic problems such as: increasing foreign debt due to insufficient revenue from exports, unpaid debts to suppliers, an import mentality that contravenes initiative and creativity, widespread corruption, and very low level of savings. To confront these problems, he proposed the following measures [Díaz-Canel, 2019a]:

- planning system: move away from current inefficient material allocation of resources towards economic and financial allotment;

- state enterprises: decentralize and grant them real autonomy; clearly define state functions as owner and administrator; replace current administrative controls by indirect regulatory mechanisms, such as economic and financial incentives; eliminate state subsidies to enterprises;

- local government: provide it with more autonomy, authority and decision-making power;

- foreign investment: put in place additional guarantees to investors regarding settlement of their obligations (e.g., repatriation of enterprise profits); pay the current debt from retained profits by such gains in Cuban currency at favorable exchange rates, hence allowing the foreign company to pay expenses in national currency; expedite supplies of inputs for import- substitution operations; provide financial stimuli in direct investment agreements to promote exports and disincentivize imports; support insertion of foreign-invested operation in value chains (e.g., chains of hotels and restaurants); create a new entity under the Council of Ministers to promote foreign investment; and allow Cubans abroad to invest in the island;

- non-state sector: enact an enterprise law that eliminates barriers and grants authorization to micro-businesses; eliminate redundant and unnecessary regulations; establish a national agency to oversee cooperatives, and convert some of them into micro- and medium-size enterprises ${ }^{9}$;

\footnotetext{
${ }^{9}$ At the time this paper was being finalized, new regulations for non-agricultural and services cooperatives were enacted that banned the creation of new ones [Decretos-Leyes 366 y 356, 2019].
} 
- exchange rate: continue the devaluation process (actually it has not started yet, save for some experiments in the past); redesign the monetary system;

- foreign trade: decentralize it;

- prices: make them more flexible, set them by agreement between the parties;

- salaries: the wage increase in the budgeted sector is the first step of a process of integral reform of the salary system;

- food supply: stabilize the supply of essential foods, which were quite scarce in the first half of 2019 (some measures have been announced); and

- multinational financial institutions: seek avenues to join them.

The above measures are appropriate but there are some caveats: First, several of them have been tried before in Cuba and then disregarded, e. g., enterprise autonomy and decentralization as well as allocation of resources through financial-economic indicators rather by administrative tools (self-financing) were the subject of discussion in the economic policy debate of 1961-1966; they were attempted in the 1980s and Raúl's reforms included decentralization of state enterprises but these policies were not implemented. Hence it is essential to wait if they are actually enforced. Second, they are still mere proposals (some schematic) that require more elaboration, debate, testing, first efforts at evaluation of their effects and implementation. Third, some measures are contradictory, for instance, the capping of prices in the private sector in August 2019 - to avoid inflation induced by the big wage increase - is an administrative action, opposite to the proposed indirect regulatory mechanisms, such as economic and financial incentives.

Fourth and the most important, the list above does not address key needed measures to accelerate and deepen the reforms which are endorsed by several well-known Cuban economists ${ }^{10}$ :

- consider the successful Sino-Vietnamese model, under the Communist party, especially in agriculture;

- implement unification of the exchange rate and of the dual currency;

- carry out a comprehensive price reform;

- infuse more flexibility in the non-state sector, particularly private, so that it grows and contributes more to the economy;

- authorize professionals to work as self-employed, eliminate excessive barriers to self-employment, and replace the current list of authorized activities by one specifying which are the ones banned and giving freedom on the rest;

- end the experimental stage for non-agricultural and services cooperatives, approve more of them and create second degree cooperatives;

- eliminate the compulsory sale of crops by farmers to the state, at prices set by the government below the market price (acopio) allowing farmers to plant what they want and sell all their crops to whoever they please at prices set by supply and demand;

- establish wholesale markets that supply needed inputs to the non-state sector; and

- allow foreign companies to contract and pay directly to their employees.

In the 1990s, Fidel Castro introduced modest economic reforms that contained the severe crisis, todays leadership should follow his approach to confront the current crisis in Cuba.

10 The opinions of a dozen prominent Cuban economists are summarized in [Mesa-Lago, 2019]. 


\section{Conclusions}

The four hypotheses in this study have been proven with abundant primary sources and robust evidence: mainly official statistics, the work of several Cuban scholars and our own analysis.

Although somewhat reduced in the last two decades, external economic dependence persists making the island vulnerable to crises endured by the foreign partner over which Cuba lacks any control. Cuba's economic relationship with the USSR totaled 65,000 $\mathrm{mln}$ doll. US in 1960-1990 and about 107,000 mln doll. US with Venezuela in 2007-2017; a significant part of which consisted in price subsidies to exports of raw materials and professional services, as well as to oil imports. Under Soviet aid, Cuba enjoyed a booming period in the 1980s, whereas in the case of Venezuela the best economic years were 2005-2007, GDP rates didn't recover such growth thereafter despite the rising Venezuelan aid in 2009-2014; with the decline in the relationship since 2016 Cuban GDP stagnated.

Despite the substantial external aid, Cuba's inability to finance her imports with her own exports continues (exports in 2018 were $48 \%$ of those in 1989 whereas imports were $41 \%$ above). Such structural conundrum has been aggravated, domestically, by an inefficient economic model of central planning, not substantially transformed by the economic reforms of 2007-2017 and the current continuity in policies, and externally by the US embargo/blockade significantly tightened by Trump's punitive policies. As a result, economic performance has been inadequate: GDP has been stagnant in the last four years; gross capital formation is about one third of both what it was in 1989 and of the government growth target; inflationary pressure is approaching the worst years of the 1990s crisis; the fiscal deficit shows a rising trend; with few exceptions, output in agriculture, fishing, mining and manufacturing have declined in the last decade and in most cases is below the 1989 level; tourism is the best performer but net revenue is $40 \%$ of gross revenue (due to high cost of imports for tourists) and declined in 2019 due to Trump's sanctions.

The crisis in Venezuela has led to an equivalent loss of 14 percentage points off of Cuba's GDP, mainly due to a $30 \%$ decrease in the value of exports of professional services and a $70 \%$ decline in oil imports; if the current relationship ends, it will cost Cuba another 8 percentage points of GDP. It was not possible to measure the cost of Trump's measures against Cuba, but they are already provoking a loss of tourist revenue of about $1 \mathrm{mln}$ doll. US, obstructing the supply of oil from Venezuela (aggravated by a decrease of $17 \%$ in domestic oil output), and probably freezing foreign investment. There is a low probability that either Russia or China will fully replace Venezuela; Russian agreements in 2019 account to $4 \%$ of the total value of Venezuela's relationship. It is expected, however, that the ongoing crisis should have lesser magnitude that the one in the 1990s because of several factors that have improved, most of them external (trade-partner diversification, remittances, tourism and investment), but Trump's sanctions make all of them vulnerable.

The first wave of government policies to confront the crisis was at best inadequate; a subsequent second wave of rough proposals are more appropriate but with important caveats. Cuban economists have suggested more profound reforms that so far are not contemplated in the official program but are fundamental to take Cuba out of the current abyss and provide hope for a better future. 


\section{References}

AFP (2019) Association of Fundraising Professionals. Available at: https://community.afpglobal.org/afpcagreaterlosangeleschapter/current-newsletter/new-item563495309 (accessed: 05.08.2019).

Bancos extranjeros temerosos de hacer transacciones con Cuba. (2019) Cuba Encuentro. Available at: https:// www.cubaencuentro.com/cuba/noticias/bancos (accessed: 05.08.2019).

Betancourt R. (2001) Review of Comparative Policy and Performance. Cuba in Transition, vol. 11, pp. 227-232.

Boorstein E. (1968) The Economic Transformation of Cuba. New York, Monthly Review Press. 303 p.

Casey N. (2019) "No turning back, declares Guaidó amid standoff". New York Times, May 2. Available at: https://www.nytimes.com/2019/05/01/world/americas/venezuela-protests-guaido-maduro.html (accessed: 05.08.2019).

Castro R. (2019) Discurso en la Segunda Sesión Extraordinaria de la XI Legislatura de la ANPP. Vanguardia, April 11. Available at: www.cmhw.cu/nacionales/19056-discurso-del-general (accessed: 05.08.2019).

Chase-Dunn C. (2015) Dependency Theory. International Encyclopedia of the Social and Behavioral Sciences, $2^{\text {nd }}$ Edition, Elsevier Ltd. 23185 p.

Cuba withdraws its doctors from Bolivia. (2019) Havana, 14ymedio, November 15. Available at: https://translatingcuba.com/cuba-withdraws-its (accessed: 05.08.2019).

CERP (1965) Cuban Economic Research Project. A Study on Cuba. Coral Gables, University of Miami. $516 \mathrm{p}$.

CEE (1991) Comité Estatal de Estadísticas. Anuario Estadístico de Cuba 1989. Havana. 400 p.

Cuba Standard (2018) Economic Trend Report, Third Quarter, pp. 8-9.

De Miranda M. (2009) Los problemas de la inserción internacional de Cuba y su relación con el desarrollo económico. Madrid, Universidad Complutense. 505 p. Available at: https://eprints.ucm.es/8624/ (accessed: 05.08.2019).

Decretos-Leyes 366 y 356. (2019) Gaceta Oficial, 30 agosto. Available at: http://juriscuba.com/legislacion-2/ decretos-leyes/ (accessed: 05.08.2019).

Delgado A. (2019) Decisión en Washington podría definir si activos de Chevron en Venezuela. El Nuevo Herald, October 18. Available at: https://www.elnuevoherald.com/noticias/mundo/america-latina/ venezuela-es/article236415008.html (accessed: 05.08.2019).

Díaz-Canel M. (2019a) Discurso de clausura del 8vo. Congreso de la Asociación Nacional de Economistas y Contadores de Cuba. Juventud Rebelde, June 4. Available at: https://www.presidencia.gob.cu/es/noticias/ (accessed: 05.08.2019).

Díaz-Canel M. (2019b) Discurso de clausura del Tercer Período Ordinario de Sesiones de la IX Legislatura de la ANPP. July 13. Available at : www.radioangulo.cu/cuba/237463-discurso-de-diaz (accessed: 05.08.2019).

ECLAC (2019a) Economic Commission for Latin America and the Caribbean. Estudio Económico de América Latina y el Caribe 2019, Santiago, July 31, 235 p.

ECLAC (2019b) Economic Commission for Latin America and the Caribbean. Nota de Cuba, Santiago.

Ecuador end is medical agreements with Cuba. (2019) Havana, 14ymedio, November 12. Available at: translatingcuba.com/ecuador-ends-its-medical-agreements-with-cuba (accessed: 05.08.2019).

Farber S. (2011) Cuba since the Revolution of 1959. Chicago, Haymarket. 369 p.

Figueredo O., Doimeadios D., Izquierdo L., Padron A., Romeo L., Perez I. (2019) Pese a restricciones financieras, Cuba cumple niveles de producción esenciales en el primer semestre de 2019. Cubadebate, July 13. Available at: www.cubadebate.cu/noticias/2019/07/13/pese-a-rest (accessed: 05.08.2019).

Frank M. (2019) Tougher U.S. sanctions make Cuba even more difficult for Western firms. U.S. News and World Report, October 10. Available at: https://www.usnews.com/news/world/articles/2019-10 (accessed: 05.08.2019).

Fuentes T. (2018) Cuba proyecta para 2019 un aumento del 17\% de sus ingresos turísticos. Cuba y la Economía, November 19. Available at: https://cubayeconomia.blogspot.com/2018/11/cuba (accessed: 05.08.2019).

Gil A. (2019a) Ministro de economía: Importar menos y producir más. Cuba Debate, April 13. Available at: www.cubadebate.cu/noticias/2019/04/13/ministro-de (accessed: 05.08.2019).

Gil A. (2019b) Cubadebate en Mesa Redonda. Cuba Debate TV, June 25. Available at: https://www.youtube. com/watch?v=Uxm-AZqB1WM (accessed: 05.08.2019).

Informe de la Delegación de Cuba a XIII Período de Sesiones de la CEPAL.(1969) Santiago de Chile, April. Hernández-Catá E. (2013) Cuba, the Soviet Union and Venezuela: A Tale of Dependence and Sock. Cuba in Transition, vol. 23. Miami, ASCE, pp. 195-204. 
Herrera H. (2019) Breves notas para un turismo resiliente en Cuba. Cuba y la Economía, March 13. Available at: https://cubayeconomia.blogspot.com/2019/05/breves (accessed: 05.08.2019).

Kassai L., Bartenstein B. (2019) Vessels change names of go dark to ship Venezuelan crude to Cuba. Bloomberg, July 9. Available at: https://www.bloomberg.com/news/articles/2019-07-08/ (accessed: 05.08.2019).

Krauss C. (2019) The struggle to keep Citgo in one piece. The New York Times, October 18.

Marrero M. (2019) Ministros de turismo e industrias informan de su gestión ante el parlamento. Juventud Rebelde, July 11. Available at: http://www.juventudrebelde.cu/galeria/cobertura-especial-ministrosde-turismo-e-industria-informan-sobre-su-gestion-al-parlamento-de-cuba-infografia (accessed: 05.08.2019).

Mesa-Lago C. (1971) Economic Policies and Growth. In: Revolutionary Change in Cuba. Ed. by C. MesaLago. Pittsburgh, University of Pittsburgh Press, pp. 277-338.

Mesa-Lago C. (1981) The Economy of Socialist Cuba: A Two Decade-Appraisal. Albuquerque, University of New Mexico Press, 235 p.

Mesa-Lago C. (2000) Market, Socialist and Mixed Economies: Comparative Policies and Performance-Chile, Cuba and Costa Rica. Baltimore, John Hopkins University Press. 707 p.

Mesa-Lago C. (2018) La economía cubana: situación en 2017-2018 y perspectivas para 2019. Havana, Cuba Posible, December.

Mesa-Lago C. (2019) Las medidas propuestas por los economistas cubanos frente a la crisis. OnCuba, Havana, September 25.

Mesa-Lago C., R. Veiga, L. González, S. Vera and A.l Pérez-Liñán (2018) Voices of Change in the Non-State Sector in Cuba. Pittsburgh, University of Pittsburgh Press. 178 p.

Mesa-Lago C., Vidal P.(2019) El impacto en la economía cubana de la crisis en Venezuela y las políticas de Trump, Madrid, Instituto Elcano de Asuntos Internacionales, Documento de Trabajo, May 2019. 25 p.

Mojena B. (2019) Cómo las medidas de Trump han impactado a los trabajadores no estatales cubanos. June 16. Available at: http://www.granma.cu/helms-burton/2019-06-16/como-las-medidas-unilateralesde-washington-han-impactado-a-los-trabajadores-no-estatales-cubanos-16-06-2019-20-06-36 (accessed: 05.08.2019).

Monreal P.(2019) La corrección estadística del crecimiento del agro cubano en 2018: entre la probabilidad y la posibilidad. Elestadocomotal, July 15. Available at: https://elestadocomotal.com/2019/07/15/la (accessed: 05.08.2019).

Morales E. (2019a) Special Period Around the Corner? THCG Business Report, no. 2, April - June, pp. 12-17.

O'Connor J. (1970) The Origins of Socialism in Cuba. Ithaca, Cornel University Press. 338 p.

ONEI (1991)Oficina Nacional de Estadística e Información. Anuario Estadístico de Cuba 2007, Havana. Available at: http://www.onei.gob.cu (accessed: 05.08.2019).

ONEI (1998) Oficina Nacional de Estadística e Información. Anuario Estadístico de Cuba 2007, Havana. Available at: http://www.onei.gob.cu (accessed: 05.08.2019).

ONEI (2001) Oficina Nacional de Estadística e Información. Anuario Estadístico de Cuba 2007, Havana. Available at: http://www.onei.gob.cu (accessed: 05.08.2019).

ONEI (2007) Oficina Nacional de Estadística e Información. Anuario Estadístico de Cuba 2007, Havana. Available at: http://www.onei.gob.cu (accessed: 05.08.2019).

ONEI (2008) Oficina Nacional de Estadística e Información. Anuario Estadístico de Cuba 2008, Havana. Available at: http://www.onei.gob.cu (accessed: 05.08.2019).

ONEI (2009) Oficina Nacional de Estadística e Información. Anuario Estadístico de Cuba 2009, Havana. Available at: http://www.onei.gob.cu (accessed: 05.08.2019).

ONEI (2010) Oficina Nacional de Estadística e Información. Anuario Estadístico de Cuba 2010, Havana. Available at: http://www.onei.gob.cu (accessed: 05.08.2019).

ONEI (2011) Oficina Nacional de Estadística e Información. Anuario Estadístico de Cuba 2011, Havana. Available at: http://www.onei.gob.cu (accessed: 05.08.2019).

ONEI (2012) Oficina Nacional de Estadística e Información. Anuario Estadístico de Cuba 2012, Havana. Available at: http://www.onei.gob.cu (accessed: 05.08.2019).

ONEI (2013) Oficina Nacional de Estadística e Información. Anuario Estadístico de Cuba 2013, Havana. Available at: http://www.onei.gob.cu (accessed: 05.08.2019).

ONEI (2014) Oficina Nacional de Estadística e Información. Anuario Estadístico de Cuba 2014, Havana. Available at: http://www.onei.gob.cu (accessed: 05.08.2019).

ONEI (2015) Oficina Nacional de Estadística e Información. Anuario Estadístico de Cuba 2015, Havana. Available at: http://www.onei.gob.cu (accessed: 05.08.2019). 
ONEI (2016) Oficina Nacional de Estadística e Información. Anuario Estadístico de Cuba 2016, Havana. Available at: http://www.onei.gob.cu (accessed: 05.08.2019).

ONEI (2017) Oficina Nacional de Estadística e Información. Anuario Estadístico de Cuba 2017, Havana. Available at: http://www.onei.gob.cu (accessed: 05.08.2019).

ONEI (2018) Oficina Nacional de Estadística e Información. Anuario Estadístico de Cuba 2018, Havana. Available at: http://www.onei.gob.cu (accessed: 05.08.2019).

ONEI (2019) Oficina Nacional de Estadística e Información. Turismo: Llegada de visitantes internacionales, enero-julio 2019, p. 1. Available at: http://www.onei.gob.cu (accessed: 05.08.2019).

Pentón M. (2019) EEUU anuncia nuevas medidas contra el gobierno cubano. El Nuevo Herald, October 18. Available at: https://www.elnuevoherald.com/noticias/mundo/ (accessed: 05.08.2019).

Perelló J.L. (2018) El turismo en Cuba comienza a recuperarse (resumen del primer semestre). Excelencias News Cuba, July 30. Available at: https://www.excelenciascuba.com/noticia/el-turismo (accessed: 05.08.2019).

Perelló J.L.(2019) Actualidad del sector turístico cubano y cómo convertir amenazas en oportunidades. Excelencias News Cuba, July 17. Available at: https://www.excelenciascuba.com/turismo-turismo (accessed: 05.08.2019).

Pérez-López J.(1991) Swimming Against the Tide: Implications for Cuba of Soviet and Eastern European Reforms in Foreign Economic Relations. Journal of Interamerican Studies and World Affairs, vol. 33, no. 2, pp. 81-139.

Pérez-López J. (2017) Cuba’s Never Ending External Sector Crisis. Cuba in Transition, Miami, ASCE, vol. 27, p. 30-44.

Pérez Villanueva O.E.(2019) La inversión extranjera directa en Cuba. Horizonte Cubano. December 17, pp. 37-52

Piñón J. (2019) Information to the author on Cuba's oil needs, supply and deficit, July 3.

Revelan cuanto cobró Cuba por venta de salud en 2018. (2019) 14ymedio, August 3. Available at: https:// www.14ymedio.com/nacional/Revelan-Cuba-servicios-criticas-Bolsonaro_0_2703929582.html (accessed: 05.08.2019).

Rodríguez J. L. (1989) El desarrollo económico y social en Cuba: Resultados de 30 años de revolución. Cuba Socialista, vol. 9, no. 3, May - June, pp. 35-65.

Rodríguez J. L. (2019). Resumen sobre la evolución de la economía mundial primer semestre de 2019. Cuba y la Economía, September 2. Available at: https://cubayeconomia.blogspot.com/2019/09/impactospara-cuba-de-la-evolucion-mas.html

Rogers K. (2019) U. S. issues warning to Cubans over Maduro. New York Times, April 30. Available at: https:// www.nytimes.com/2019/04/30/us/politics/trump-maduro-cuba.html (accessed: 05.08.2019).

Romeo L. (2019) Trabajadores del turismo: necesidad de elevar la calidad. El Economista de Cuba, April 21. Available at: www.eleconomista.cubaweb.cu/2019/nro640/mercado.html (accessed: 05.08.2019).

Romero C. (2018) Venezuela and Cuba. Cuban Foreign Policy Transformation Under Raúl Castro. Boulder, Roman and Littlefield Publishers Inc., pp. 211-226.

Santamaría A. (2014) Economía Cubana y la Relación con España, 1765-1902. Colección Tierra Nueva. 496 p.

Torres R. (2019) Se exacerban las presiones en la balanza de pagos cubana. Red Ecolatin Cuba, July 23. Available at: https://www.cesla.com/informe-economia-cuba.php (accessed: 05.08.2019).

United States (2019) State Department, Updating of Regulations on Cuba, Washington D. C., June 4. Available at: https://www.state.gov/united-states-restricts-travel-and-vessels-to-cuba (accessed: 05.08.2019).

OFAC (2019) U.S. Office of Foreign Assets Control, Press release, September 24. Available at: https://www. jdsupra.com/legalnews/ofac-amends-cuba-sanctions-to-limit-11863 (accessed: 05.08.2019).

Vidal P. (2014), Proyecciones Económicas de una Cuba sin Venezuela. Desde la Isla, Cuba Study Group, pp. $1-8$.

Zimbalist A., Eckstein S. (1987) Patterns of Cuban Development: The First Twenty Five Years. In: Cuba's Socialist Economy Toward the 1990s. Ed. by A.Zimbalist. Boulder, Lynne Rienner, pp. 7-24.

Received: 08.11.2019

Accepted: 01.06.2020

Author's information:

Carmelo Mesa-Lago — PhD, Distinguished Service Professor Emeritus; cmesa@usa.net 


\title{
Загадка развития кубинской экономики после революции (1959-2019 гг.)
}

\author{
K. Меса-Лаго
}

Университет Питтсбурга, США, 15260, Пенсильвания, Питтсбург, Пятая Авеню, 4200

Для цитирования: Mesa-Lago C. (2020) Assessing the conundrums of the Cuban economy under the revolution (1959-2019). Вестник Санкт-Петербургского университета. Экономика. Т. 36. Вып. 3. С.455-482. https://doi.org/10.21638/spbu05.2020.305

В статье оцениваются проблемы, с которыми сталкивалась экономика Кубы в течение шести десятилетий после революции (1959-2019 гг.), преимущественно связанные с ее исторической внешнеэкономической зависимостью от иностранных государств (СССР и Венесуэлы) и неблагоприятными последствиями, возникшими в условиях окончания или ухудшения отношений с данными государствами. Некоторые гипотезы исследования касаются также других проблем, среди которых - препятствие эмбарго/ блокаде США, усугубляющееся карательными санкциями Д. Трампа, кубинская преемственность централизованной планируемой экономики и преобладание государственных предприятий над рынком и негосударственным сектором. Основным методом исследования является анализ эффективности ключевых экономических показателей, таких как: рост ВВП, валовое накопление, финансовая стабильность, объем производства в горнодобывающей промышленности и сельском хозяйстве, туризм и экспорт профессиональных услуг. Гипотезы тестируются на многолетних статистических рядах, разработанных и изученных автором в течение полувека на основании кубинских официальных источников, а также законодательства, статей кубинских ученых и средств массовой информации. Можно выделить следующие результаты анализа: внешняя зависимость несколько снизилась, но требует более глубоких экономических реформ; в настоящее время нет стран, способных и желающих полностью заменить существенную помощь Венесуэлы; продолжающийся кризис, спровоцированный ухудшающейся венесуэльской экономикой и санкциями Трампа, должен иметь менее негативные последствия, чем кризис 1990-х гг., возникший в результате исчезновения СССР. Выводы, полученные в статье, внесут вклад в изучение внешнеэкономической зависимости Кубы и последствий данной зависимости, а также могут быть использованы для анализа экономики других социалистических государств.

Ключевые слова: кубинская экономика в 1959-2019 гг., внешнеэкономическая зависимость, экономические отношения СССР и Венесуэлы, оценка экономических показателей, влияние на Кубу кризиса Венесуэлы и санкций Трампа, кризис и антикризисная политика.

Статья поступила в редакцию: 08.11.2019

Статья рекомендована в печать: 01.06.2020

Контактная информация:

Меса-Лаго Кармело - д-р наук, заслуженный проф.; cmesa@usa.net 